\title{
Comparison of a new "U" shaped plastic fish tank system to the traditional concrete raceway system
}

Daniel J. Miller

West Virginia University

Follow this and additional works at: https://researchrepository.wvu.edu/etd

\section{Recommended Citation}

Miller, Daniel J., "Comparison of a new "U" shaped plastic fish tank system to the traditional concrete raceway system" (2008). Graduate Theses, Dissertations, and Problem Reports. 2709.

https://researchrepository.wvu.edu/etd/2709

This Dissertation is protected by copyright and/or related rights. It has been brought to you by the The Research Repository @ WVU with permission from the rights-holder(s). You are free to use this Dissertation in any way that is permitted by the copyright and related rights legislation that applies to your use. For other uses you must obtain permission from the rights-holder(s) directly, unless additional rights are indicated by a Creative Commons license in the record and/ or on the work itself. This Dissertation has been accepted for inclusion in WVU Graduate Theses, Dissertations, and Problem Reports collection by an authorized administrator of The Research Repository @ WVU.

For more information, please contact researchrepository@mail.wvu.edu. 
Comparison of a New "U" Shaped Plastic Fish Tank System to the Traditional Concrete Raceway System

\author{
Daniel J. Miller
}

Dissertation submitted to the

Davis College of Agriculture, Forestry, and Consumer Sciences

at West Virginia University

in partial fulfillment of the requirements

for the degree of

\title{
Doctor of Philosophy
}

in

Resource Management and Sustainable Development

Major: Agricultural and Extension Education

Stacy A. Gartin, Ph.D., Chair

Harry N. Boone Jr., Ph.D.

Deborah A. Boone, Ph.D.

Gerard D'Souza, Ph.D.

J. Todd Petty, Ph.D.

Division of Resource Management

Morgantown, West Virginia

2008

Keywords: "U" shaped plastic tank, aquaculture, comparison Copyright 2008 Daniel J. Miller 


\begin{abstract}
Comparison of a New “U” Shaped Plastic Fish Tank System

to the Traditional Concrete Raceway System
\end{abstract}

Daniel J. Miller

The goal of this research was to compare the cost of purchasing, installing and operating a new plastic "U" shaped raceway (fish tank) to the traditional concrete flat-bottomed raceways used in many federal, state, and private fish hatcheries. Potential benefits of this new design include lower fixed (purchase and installation) costs, ease of mobility due to its light weight, reduced operational cost due to the rapid cleaning process that the "U" shape allows, and the simplicity with which modifications can be made to the tank to suit the operation. Limitations include width and depth restrictions and greater vulnerability to vandalism than concrete.

Nine 2000 gallon plastic tanks were stocked with 1000 four inch rainbow trout fingerlings in November of 2006. The same batch of trout (cohorts) was used to stock a flat-bottomed concrete tank of similar volume and at a similar density in a commercial hatchery with a similar biosecure water source. Both populations were fed a high energy commercial trout feed throughout the 31 week growout period. Growth, mortality and fin condition were measured.

Results from this research showed that the high density polyethylene (HDPE) plastic tanks cost $47 \%$ less to purchase, install, and operate, than the similar volume pre-cast concrete tanks. At market size $(1 \mathrm{lb}$.) fin condition of the trout in the plastic tanks were similar to trout in concrete tanks. A rapid bioassessment of the receiving stream during the research resulted in a diverse group of benthic macroinvertebrates, which indicate the production levels appear to be sustainable at this site.

West Virginia University has received a provisional patent on this design and plans to license a U. S. based manufacturer to make the low cost tank. An international aquaculture supply company is interested in obtaining the rights to sell this new product. 


\section{DEDICATION}

This effort is dedicated to the development of economic and environmental sustainability in the aquaculture industry. It is also dedicated to my lovely wife Lee Ann and our two inspiring girls Genevieve and Talia. 


\section{ACKNOWLEDGEMENTS}

Funding for this research was provided by the Northeast Regional Aquaculture Center (NRAC grant \# 2002-38500-12056) by way of the U. S. Department of Agriculture. Additional support was provided by Eastern Associated Coal Company.

West Virginia University administered the grant funding. The Extension Service provided vehicle support for transportation to and from the research site.

I want to thank all of my committee members for providing guidance and encouragement during the planning, implementation, and evaluation of this effort. Dr. D'Souza provided subtle encouragement to pursue this degree shortly after we began working together on the aquaculture grant project. Dr. Harry Boone made learning about research methods far less intimidating than was expected. Dr. Deborah Boone shared her expertise in program development and evaluation which has proven useful in identifying and targeting the proper audience for marketing the new plastic tank. Dr. Petty provided valuable suggestions early in the planning of the research that helped to improve the monitoring of the two water sources. Dr Gartin greatly reduced the level of stress associated with this undertaking by clearly explaining the process and responsibilities of the committee and the student. I am grateful to my committee for actually making this process an enjoyable experience. 


\section{TABLE OF CONTENTS}

ABSTRACT

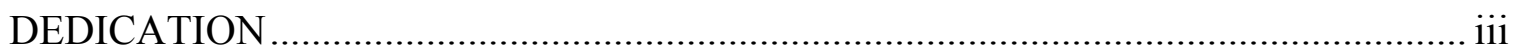

ACKNOWLEDGEMENTS ............................................................................... iv

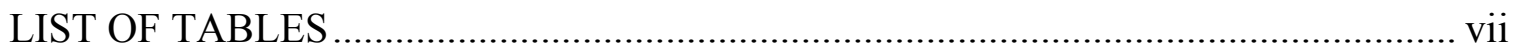

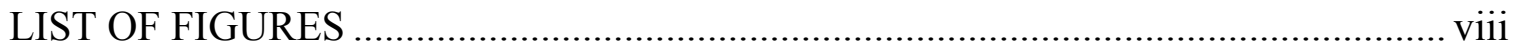

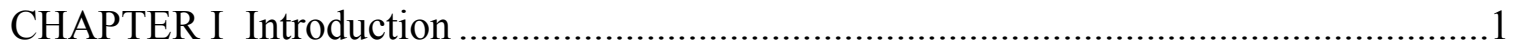

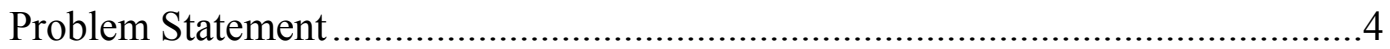

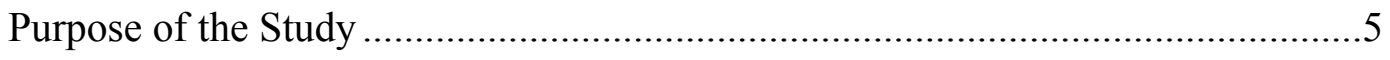

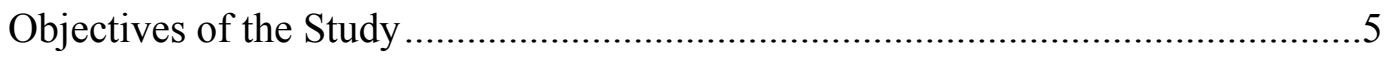

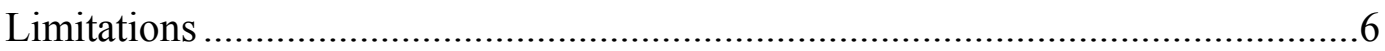

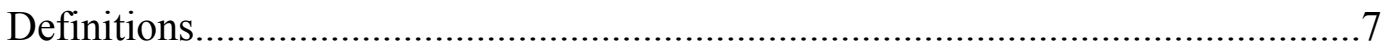

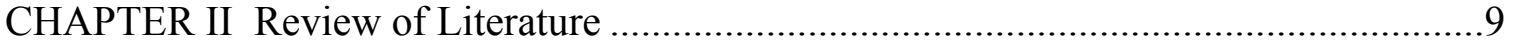

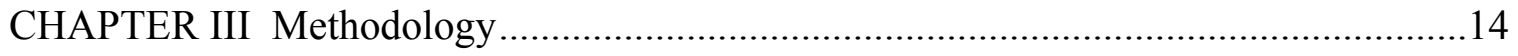

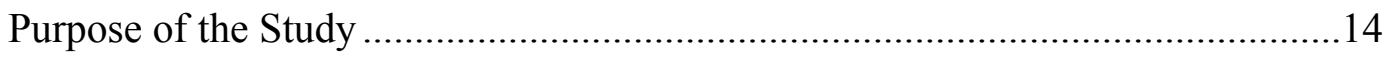

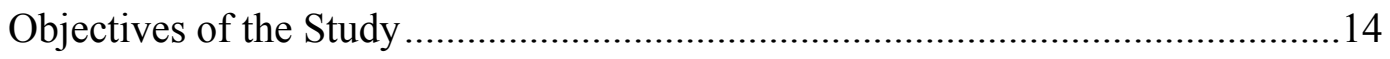

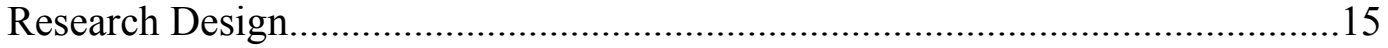

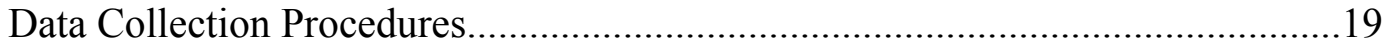

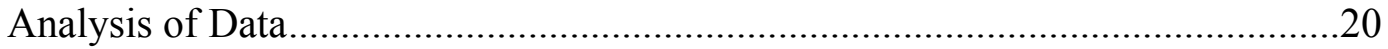

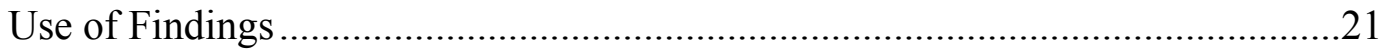

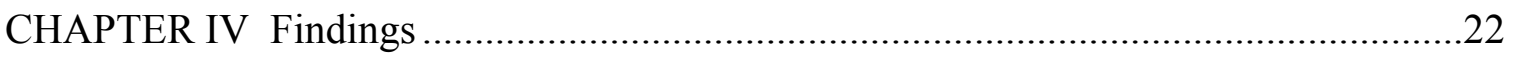

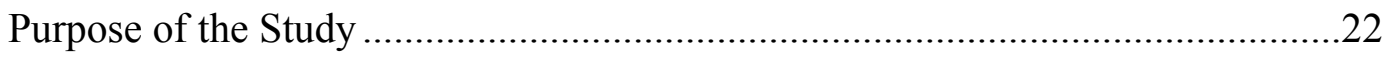

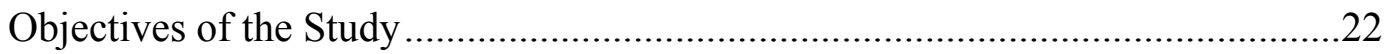

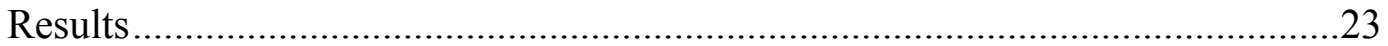

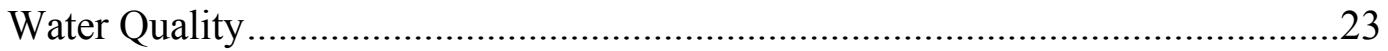

Annual Maintenance / Cleaning Costs...............................................................26

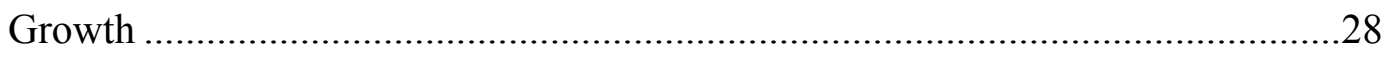

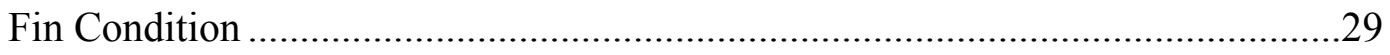

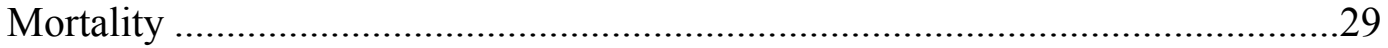

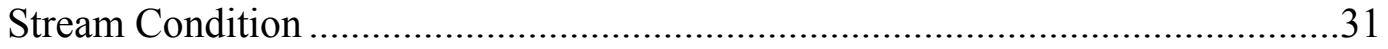

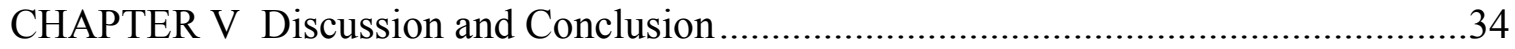

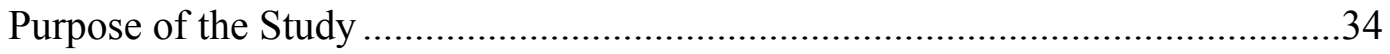




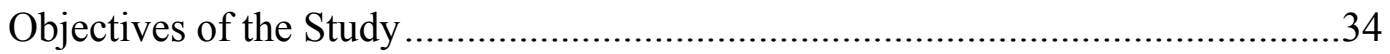

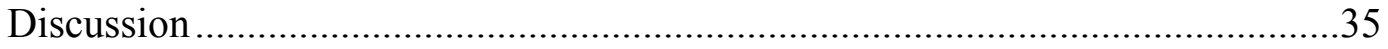

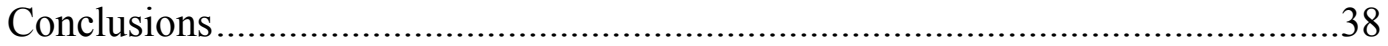

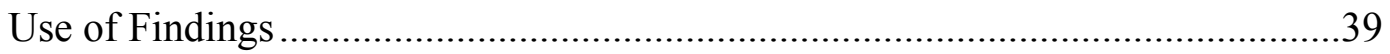

Recommendations and Implications ........................................................... 40

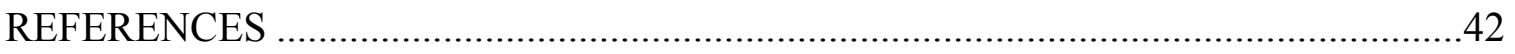

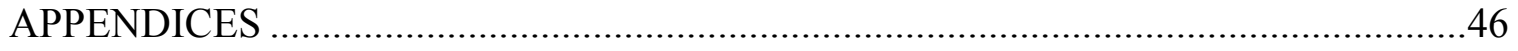

APPENDIX A: Budget for: 20,000 pound per year trout farm -

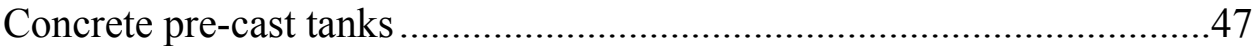

APPENDIX B: Budget for: 20,000 pound per year trout farm -

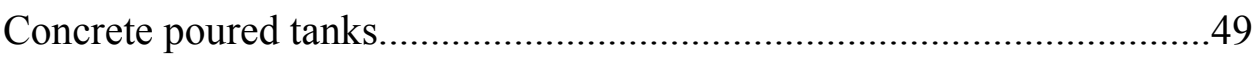

APPENDIX C: Budget for: 20,000 pound per year trout farm -

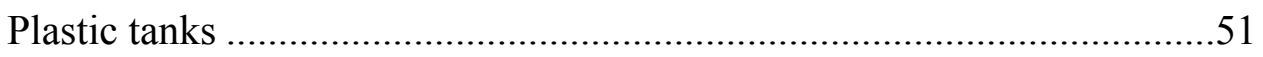

APPENDIX D: Photo of a model high density polyethylene (HDPE) tank .........54

VITA 


\section{LIST OF TABLES}

Table Title Page

$1 \quad$ Water Chemistry Data From the Two Water Sources.....................................25

2 Cost Comparison for Concrete and Plastic Tank System (10 tanks) ................26

3 Net Present Value Over 10 Years for a 20,000 lb. / year Fish Farm ................27

$4 \quad$ Internal Rate of Return for a 20,000 lb. / year Fish Farm .............................28

$5 \quad$ Growth, Condition Factor, Fin Condition, and Mortality From Concrete and Plastic Tanks..............................................................................29

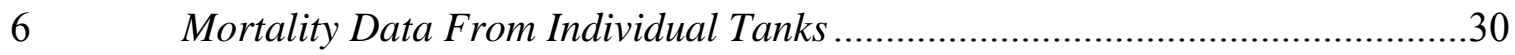

7 Benthic Macroinvertebrates Collected From Hopkins Fork, Spring ...............32

8 Comparisons Between Concrete and Plastic (HDPE) Fish Tanks. ..................37 


\section{LIST OF FIGURES}

Figure

Title

Page

1

Plastic (HDPE) research tanks with demand feeders and netting. ...........16

2

Screen and settling area showing collection of solids around the solid drain pipe on the bottom of the tank. .... 16

3

Model of a High density polypropelyne (HDPE) tank ..............................55 


\section{CHAPTER I}

Introduction

Traditionally trout have been raised for stocking purposes in concrete rectangular raceways due to the labor efficiency, ease of handling or harvesting, and the ability to reuse the water (Bender, Lukens, \& Ricker, 1999; Boardman, Maillard, Nyland, Flick, \& Libey, 1998). The large-scale production facilities, operated by state and federal agencies are responsible for stocking large areas for public recreational fishing. Funding for these trout production facilities usually comes from federal or state resources and profitability is not an objective.

Within the past decade a number of public hatcheries have come under increased pressure to reduce waste discharges as well as to reduce the cost of production (Ewart, Hankins, \& Bullock, 1995; Flemlin, Sugiura, \& Ferraris, 2003; Hulbert, 2000). This pressure has resulted in the closing of some hatcheries, reduced production in other hatcheries (Hulbert, 2000; Westers, 2000), and the purchase of trout from private producers to reduce the cost of stocking public waters used for recreational fishing. Private trout producers usually have smaller water sources than the larger public facilities and therefore have proportionately less production and waste. Because a private producer's production is directly related to income, there is greater incentive to maximize efficiency and the quality of the product. As more states turn to private suppliers for stocking public streams for recreational fishing, there is a growing recreational market for private trout producers to fill. This creates incentive for developing the remaining somewhat smaller flowing water sources suitable for fish 
production that will produce smaller amounts of waste and therefore may be less likely to impact receiving streams in the way larger hatcheries may impact them.

As a result of the coal mining industry, West Virginia has dozens of biosecure free flowing water sources that can be used for small scale fish production (Jenkins, Wade, Fletcher, \& Hankins, 1995). Economies of scale usually result in a higher cost of production for smaller producers, making it difficult to compete with larger operations.

Can small producers use a small mine water discharge site and a "U" shaped plastic tank to reduce their fish production costs? The advantages of this new tank may include lower purchase and installation costs, easy modifications, transportability, which allows for resale value, and reduced labor for cleaning. The disadvantages of the new tank include a life span that has yet to be determined, and like concrete tanks, if installation is not done properly, poor performance may result.

There is a need to develop these water resources in an economic and environmentally sustainable manner (Jenkins et al., 1995). The huge volume of water discharging from mining operations in West Virginia provides a relatively constant cool water temperature of about $13^{0} \mathrm{C}$ nearly ideal for commercial trout aquaculture. Two commercial examples are West Virginia Salmon and Trout in Logan County, and Allegheny Aquaculture in Boone County.

By modifying an existing product it may be possible to address the major problems associated with the concrete raceway, high fixed and variable (cleaning) costs,. By utilizing non-traditional materials, high density polyethylene (HDPE), in a nontraditional form, a "U" shaped cross-section, a comparison will be made between the two production tank designs. No published research was found focusing on trout production 
utilizing a "U" shaped structure constructed with high density polyethylene. The "U" shaped bottom of the plastic tanks should concentrate the solids toward the center of the bottom area in the quiescent zone for efficient removal.

The quiescent zone is the screened area of the raceway where fish are unable to enter. It is always located at the end, between the final screen and the discharge point, where the water pours out of the raceway. Rapid removal of the solids will be accomplished by opening a valve, connected to a horizontal perforated drain pipe located at the bottom of the quiescent zone, to allow the concentrated solids to exit through the pipe to a settling pond. The effectiveness of this rapid removal system will be measured by the amount of time it takes to remove the settled solids from the quiescent zone, versus the amount of time to remove solids from the flat bottomed concrete system of a similar production volume.

By reducing the time required to clean a quiescent zone, the cost of labor is reduced. It could be argued that a tank system that is managed with more frequent solids removal will reduce the dissolved solids discharged from the system, thereby reducing the environmental impact. Significant labor savings over the useful life of the tank would make the "U" shaped design more profitable than the traditional flat bottomed raceway.

The plastic tanks can be moved into or out of a site with relative ease. This reduces the required machinery and labor needed for construction and installation. It also allows for potential resale value, as the plastic tanks can be transferred to another site with relative ease. The total cost for materials and labor for the construction of the plastic tanks will be compared to the total cost for materials and labor for the construction of the concrete tanks. This could provide farmers that have moderate smaller flows with 
the information needed to invest in the economical design that is best suited for producing trout for the recreational market.

In the United Kingdom a study by Hoyle et al. (2007) was conducted to field test a system for macroscopic assessment of fin damage in farmed rainbow trout. A photographic key was developed to assign various levels of erosion for the seven rayed fins on the sampled trout. The photographic key was used as a reference in the field to determine fin erosion in this study.

It is known that anglers who catch stocked fish in public rivers prefer to catch a fish without eroded fins or blemishes. A grading scale for the final product based on complete development of fins and a lack of other blemishes will be developed (Hoyle et al. 2007; Wagner, Routledge \& Intelmann, 1996).

\section{Problem Statement}

Traditionally, both public and private producers have used concrete raceways for trout production. (Summerfelt, 1997; Wagner, Routledge, \& Intelmann, 1996). Concrete rectangular tanks, commonly known as raceways, have some disadvantages when it comes to efficient production of quality trout. Three problems associated with the concrete raceway design are that the flat bottoms in concrete raceways require significant labor for removal of the settled solids. Second, the fin condition of trout cultured in commercial or government run concrete raceways is often compromised due to the erosion of the soft flesh. Third, the high cost of concrete raceways for smaller production units results in a higher cost of production. Bosakowski \& Wagner (1995). noted eroded fins or facial blemishes on trout raised in concrete raceways. The fin erosion is due, in part, to the effect of a hard concrete surface on the trout's soft tissue after months of 
cultivation. Another problem with the concrete tank is the inefficient manner in which solids are concentrated and removed from the tanks (Mudrak, 1981; Summerfelt, 1997). The rectangular raceways have flat quiescent zones, or settling areas, that require regular manual siphoning or pumping of the solid waste, which increases variable costs.

By providing producers with a lightweight, easily modified tank that costs considerably less than concrete tanks, more farmers, both large and small, may decide to invest in commercial fish production.

Purpose of the Study

The purpose of this study was to compare the cost of construction, installation, waste collection, growth, and quality of fish using a non-traditional material, high density polyethylene (HDPE) in a nontraditional form ("U" shaped cross section) to the traditional concrete raceway system. The purpose was also to determine if the shape of the raceway could concentrate solid waste in a manner that will reduce the labor required to maintain a clean raceway system that will produce a high quality product. Objectives of the Study

The objective of this research was to determine the cost of an alternative raceway material, including installation, and the ability of this material to commercially produce a high quality product. The following research questions directed this study.

1. How does the cost of HDPE material used for trout culture tanks, including the cost of construction, compare to industry standard concrete materials?

2. How does the waste collection and removal from the "U" shaped HDPE tanks compare to waste collection and removal from industry standard concrete raceways? 
3. How does the fin condition of trout produced in HDPE tanks compare to trout produced at similar densities in concrete tanks?

4. Based on benthic macroinvertebrate collections, what was the stream condition index (macroinvertebrate biodiversity) of the receiving stream during the research? This will help determine if the level of trout production at this site is environmentally sustainable.

5. How does fish growth and mortality rates in HDPE tanks compare to trout produced at similar densities in concrete tanks?

\section{Limitations of the Study}

This study will be limited to the comparable price impact on the fixed costs for building a raceway system using concrete or high density polyethylene. It will also be limited to determining if the physical completeness (fin condition) of the product raised in the concrete or plastic tanks is significantly different. Because the study compared the two types of tanks located in two different water sources, the biological results are limited to water quality parameters similar to those found in this study. The financial results will be applicable to a wide variety of situations, regardless of water quality differences.

Due to the limited water supply at the research site, the concrete system, which serves as a control, will have a similar but separate ground water source. This introduces another variable of water quality. The major parameters in both water sources are similar and were monitored throughout the course of the investigation. These parameters include $\mathrm{pH}$, temperature, alkalinity, ammonia, and dissolved oxygen. In addition the common anions (Fl, $\mathrm{Cl}, \mathrm{NO}_{3}, \mathrm{NO}_{2}, \mathrm{SO}_{4}, \mathrm{PO}_{4}$ ) and cations ( $\mathrm{Si}, \mathrm{Ca}, \mathrm{Mg}, \mathrm{Fe}, \mathrm{Mn}, \mathrm{Al}$, and $\mathrm{Zn}$ ) were 
analyzed. Sample acidification was performed for cation analysis to insure accuracy.

Both sites have previously produced rainbow trout without serious problems.

Definitions

Economic sustainability - the ability to consistently produce a product for less cost than the sale price of the product.

Enterprise budget - an estimate of all income and expenses associated with a specific enterprise and an estimate of its profitability.

Environmental sustainability - the ability to use a resource without having a major negative impact on the resource or the environment. In this case the water quality below the discharge of the settling pond can be measured by the diversity of macroinvertebrates sampled in the stream.

Freeboard - The elevation drop from the top of a tank to the water surface.

HDPE - High density polyethylene, plastic.

Internal Rate of Return - the compound interest rate of the investment over a designated period of time.

Net Present Value - the discounted value of a project's net annual cash flows, less the initial investment cost.

Raceway - a long, narrow, and shallow tank with water flowing through it from one end and exiting the other end. Raceways are often used in series, allowing the water leaving one raceway to drop into the next raceway. Raceways are one type of tank and the term tank and raceway can be used interchangeably.

Small volume producer - a person or company that produces less than 50,000 pounds of fish on an annual basis. 
Small to moderate flowing water source - a constant water flow that averages less than 1000 gallons per minute but is always above 50 gallons per minute.

Stream Condition Index - a rating scale that allows streams to be compared and rated on a score of 0 to 100 . A rating of 85-100 is excellent; 70-84.9 is good; 55-69.9 is marginal; and less than 55 is poor.

Quiescent zone - the screened area of the raceway where fish are unable to enter. It is always located at the end, between the final screen and the discharge point, where the water pours out of the raceway. 


\section{CHAPTER II}

\section{Review of Literature}

Issues facing aquaculture in the twenty-first century are very different than the issues from the previous century. Because many of the biological problems of the previous century were solved, state and federal agencies have succeeded in building large hatcheries to stock many streams and rivers throughout the country (National Research Council, 1993). As a result new problems have evolved and answers are being sought to resolve them.

One of the most contentious issues that must be addressed with fish production facilities is the environmental impact of the facility (Flemlin, Sugiura, \& Ferraris, 2003). In particular the excessive discharge of phosphorus from state trout hatcheries has resulted in court actions by concerned citizens (Hulbert, 2000; Westers, 2000). Commercial feed manufacturers have responded to the need for lower environmental impacts by improving the formulations to meet the nutritional requirements of trout using heat and pressure to increase the digestibility of the commercial feed (Bergheim \& Cripps, 1998; Zeigler \& Johnson, 1998). Although these efforts have improved feed conversions and reduced the amount of waste, increasing public pressure is requiring even greater reductions in nutrient discharges from public and private hatcheries.

Environmental sustainability should be a priority for any agricultural product. In the United States, Plafkin et al. (1989) helped develop the rapid bioassessment protocols used in streams and rivers to help determine the relative quality of a stream. A modified version was developed by Barbour et al. (1999) and this protocol was used for the macroinvertebrate collection process. The diversity of macroinvertebrate communities 
have been used to determine the quality of upland streams where mining, power plants, or logging may have measurable impacts (Malmqvist \& Hoffsten 1999; Kreutzweiser, Capell, \& Good 2005). Petty (2004) assessed the thermal impact of a power plant on the receiving stream using these same protocols. Restoration efforts in mined areas have used water quality and benthic sampling to determine the outcomes of attempting to restore a stream (Petty and Barker 2004).

Wagner, Routledge, and Intelmann (1996) studied the effect concrete versus cobble substrate on fin condition and health of trout. Most studies conducted in raceways were done using traditional materials (concrete) with the traditional flat bottom (Bender, Lukens, \& Ricker, 1999; Boardman, Maillard, Nyland, Flick, \& Libey, 1998). Hoyle et al., (2006) compared the mean fin index scores calculated from the average scores of 40 commercial farms in the United Kingdom, to wild rainbow trout in the United States. This study used a scale from 0 to 5 with 5 indicating the worst condition possible. The stocking density of trout is considered a factor in fin condition and for this reason similar densities need to be maintained in this study (North et al. 2006; Wagner, Intelmann, \& Routledge, 1996). Aggressive feeding behavior is another possible cause of poor fin condition (Larmoyeux \& Piper, 1971).

No published research was found focusing on trout production utilizing a "U" shaped structure constructed with high density polyethylene. This indicates this study may be a novel approach to the problem. This lack of information may indicate that there is need for a new approach to traditional production methods when dealing with new restricting environmental issues relating to commercial trout production. This new 
approach may require smaller operations generating proportionately smaller nutrient discharges.

Feedback from the stakeholders in West Virginia has indicated a need for reducing the cost of fish production as well as a reduction in nutrient discharges. This feedback has provided an incentive for the author to focus on addressing the cost of production for smaller fish farmers. Boone, Safrit, and Jones (2002) describe the importance of developing adult education programs by carefully including all stakeholders in the process. West Virginia University's Extension Service has established links with the aquaculture community through a variety of means. The diffusion of practical information to this community occurs through site visits, seminars, demonstrations, web sites, and an annual aquaculture forum.

The process of developing aquaculture within a community or region requires continual input from leaders within the community (Caffarella, 2002). The changing needs of the aquaculture community can be properly addressed by University Extension Service personnel by utilizing site visits, seminars, demonstrations, web sites, and an annual aquaculture forum. Evaluations from the participants in extension activities have provided valuable information on the changing needs in the aquaculture community (Wholey, Hatry, \& Newcomer, 2004).

Wong and Piedrahita (2003) describe a variety of methods including particle size, density, biological responses, electrical attributes, magnetic properties, or chemical characteristics to separate solids from the aqueous flow in a raceway. Some of the methods used to improve waste collection and removal may not be practical for commercial operations. An important principle in this research is the "Keep It Simple" 
(KISS) rule. For application in the commercial world where most of the fish farms are family operated or owned, simplicity is a necessity for widespread adoption (Cafarella, 2002).

Mine water discharges have been known to contain a variety of toxins depending on the chemistry of the coal seam. Toxic heavy metals such as aluminum, cadmium, and selenium have also been associated with the coal industry (Sorensen, 1991).

\section{Summary}

The increasing demand for hatchery (farm) raised fish in the United States has led state and federal agencies responsible for stocking public waters to come into conflict with environmental organizations that claim the nutrient discharges from these hatcheries are causing excessive damage to the receiving waters. Various court actions have resulted in lowering the production levels of some hatcheries and the closing of others. In order to adapt to this changing attitude, improvement in waste management must occur. An alternative is to allow smaller private fish farmers to provide fish for the public stocking program. Recently, the Pennsylvania Fish and Boat Commission turned to private fish farmers to accommodate this need.

Utilizing smaller water sources for fish production can reduce the effluent loads because of the lower annual production from these smaller farms. However, the cost of production in smaller operations, in general, tends to increase due to economies of scale. An experimental plastic tank was tested to determine if the new shape and material would allow smaller producers to reduce their fixed and variable costs, thus allowing them to remain profitable while facing environmental issues that result in added expenses for waste management. 
The Environmental Protection Agency developed protocols for rapid bioassessment of wadeable streams and rivers in 1989 to address the many types of pollution that were reducing water quality in the United States. This protocol was utilized during the data collection to determine the quality of the receiving stream in Boone County, WV. Tetra Tech, Inc. (2000) developed a 0 to 100 scale that allows unrelated streams to be compared and classified into categories ranging from poor to excellent. 


\section{CHAPTER III}

\section{Methodology}

\section{Purpose of the Study}

The purpose of this study was to compare the cost of construction, installation, waste collection, growth, and quality of fish using a non-traditional material, high density polyethylene (HDPE) in a nontraditional form ("U" shaped cross section) to the traditional concrete raceway system. The purpose was also to determine if the shape of the raceway could concentrate solid waste in a manner that will reduce the labor required to maintain a clean raceway system that will produce a high quality product.

\section{Objectives of the Study}

The objective of this research was to determine the cost of an alternative raceway material, including installation, and the ability of this material to commercially produce a high quality product. The following research questions directed this study.

1. How does the cost of HDPE material used for trout culture tanks, including the cost of construction, compare to industry standard concrete materials?

2. How does the waste collection and removal from the "U" shaped HDPE tanks compare to waste collection and removal from industry standard concrete raceways?

3. How does the fin condition of trout produced in HDPE tanks compare to trout produced at similar densities in concrete tanks?

4. Based on benthic macroinvertebrate collections, what was the stream condition index (macroinvertebrate biodiversity) of the receiving stream during the 
research? This will help determine if the level of trout production at this site is environmentally sustainable.

5. How does fish growth and mortality rates in HDPE tanks compare to trout produced at similar densities in concrete tanks?

\section{Research Design}

A variation of the posttest only group experimental research design was employed in this study. In November of 2006 the experimental group of four inch rainbow trout fingerlings was stocked into a series of nine 2,000 gallon "U" shaped plastic tanks, thirty feet long and five feet wide at the top, at a density of about four fish per cubic foot. The plastic tanks were located in a remote area of southern West Virginia that had a reliable high quality mine water discharge. The water flow was insufficient (less than $200 \mathrm{gpm}$ in the fall) to accommodate both types of tanks so another water source of similar quality was used for the concrete tanks. A chain link fence surrounded the plastic tanks and three electrified wires around the fence were used to deter the wildlife from entering the area. The cohorts of this group, from the same hatchery, were stocked as a control at similar densities into a concrete flat bottomed tank of similar volume at a commercial trout hatchery. Both of these sites had a history of normal trout growth from previous production cycles.

A single "U" shaped raceway 30 feet long was built by horizontally cutting a 30 foot section of 5 foot diameter drainage pipe in half. End pieces were welded at both ends to create the long narrow tank (Figure 1). On the drain side of the tank a screen 
created a quiescent zone about three feet long where the solids were settled and removed (see Figure 2).

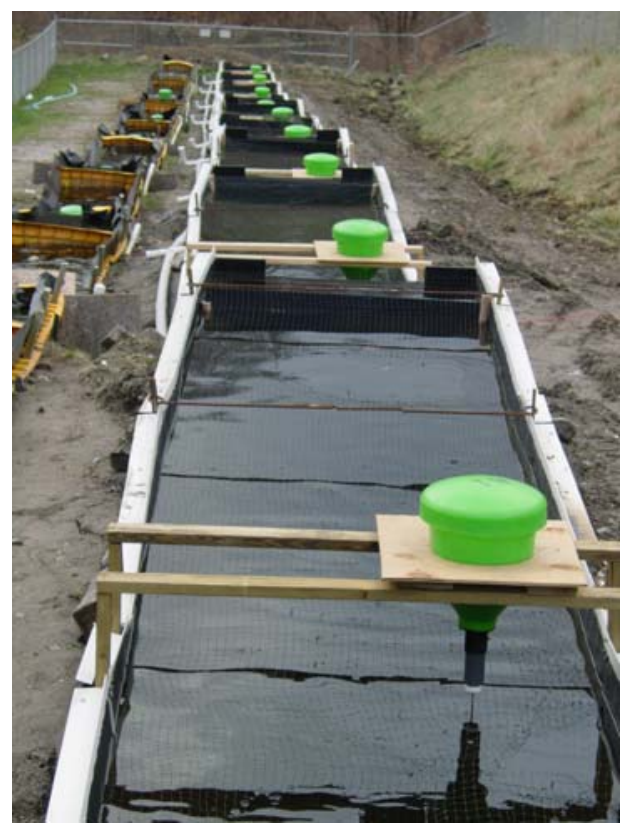

Figure 1: Plastic (HDPE) research tanks with demand feeders and netting.

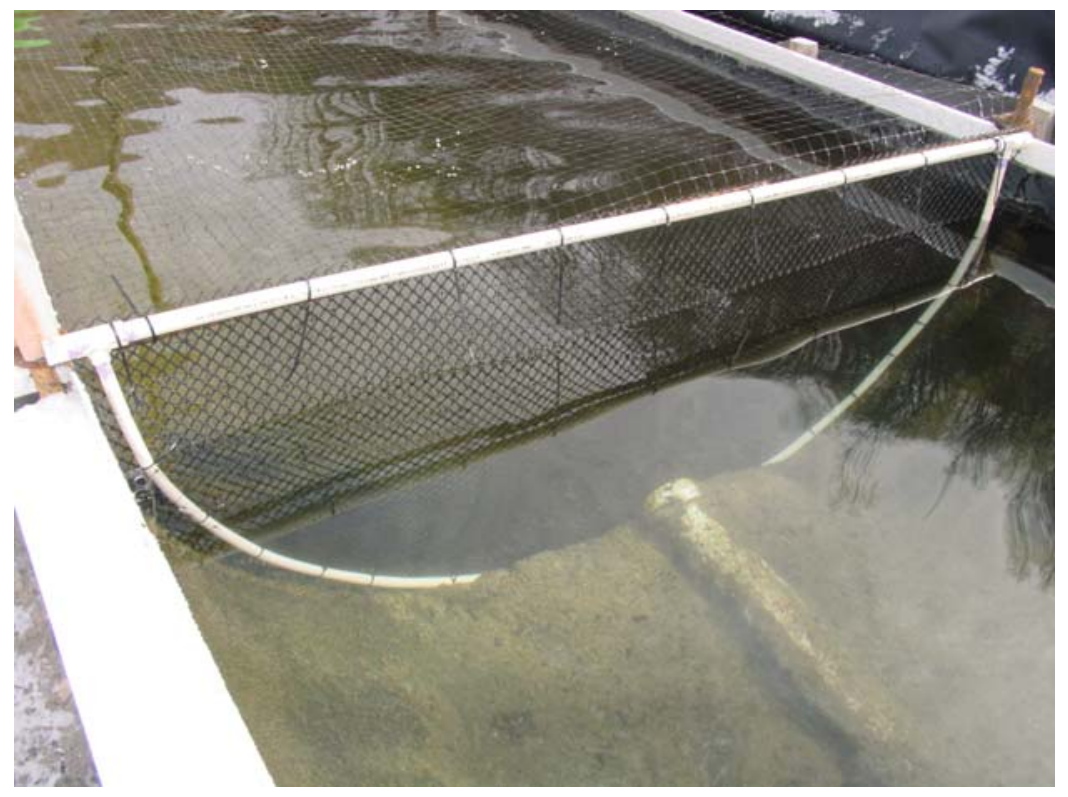

Figure 2: Screen and settling area showing collection of solids around the solid drain pipe on the bottom of the tank. 
A three inch diameter pipe enters the downstream end piece at the lowest point in order to lie directly along the center at the bottom of the quiescent zone. This three inch diameter perforated pipe was connected to an external valve that can be easily opened by the fish caretaker. If used in freezing conditions an internal gate valve could be used to reduce the risk of valve rupture from freezing. When the valve is open, water enters the pipe from the bottom of the quiescent zone, thereby allowing any settled solids to rapidly exit the raceway. All water and solid waste leaving the raceway in this manner were diverted to a settling pond.

The cross-section of the tank is a semi-circle with the widest end (60 inches) at the top, forming a "U" shape. The volume of the tank will depend on the depth of water. For practical purposes the production volume of the 30 foot long plastic tank is approximately 2000 gallons.

Commercial harvest densities of about four $1 \mathrm{bs} . / \mathrm{ft}^{3}$ are common. In order to obtain this level of production, approximately 1000 four inch trout fingerlings were stocked into each of the nine plastic raceways. Every six weeks at least 50 trout were randomly sampled and measured for average weight using a commercial Ohaus digital bench scale. As the trout neared the one pound market size, lengths from each randomly sampled fish were measured using a commercial measuring board with graduations in millimeters to obtain the condition factor. Fin condition was measured during the final growth samplings. Each of the seven rayed fins was given a number from 0 to 5 (Hoyle, et al. 2007). A zero indicated a perfect fin condition and a 5 indicated greater than $90 \%$ erosion of the fin. The null hypothesis is that there was no difference in the fin condition between the two types of tanks when the fish are a marketable one pound size. The 
hypothesis is that the plastic material will result in less fin erosion than the concrete material. Concerning growth and mortality, the hypothesis is that there was no difference in growth or mortality due to the material in which the fish were raised. The null hypothesis for waste removal is that there was no difference in the time needed to clean each type of tank. The research hypothesis is that cleaning of the plastic tank took less time than the cleaning of the concrete tank due to the design differences.

In an effort to determine variation between fin condition by observers, two observers processed the same group of fish from the concrete system. This resulted in a 7.92 mean total fin score from observer 1 and a 6.66 mean total fin score from observer two. The total possible variation was between 0 and 35 .

Both groups of trout were fed a high protein (42\%) high fat (16\%) commercial trout diet throughout the 31 week production cycle. A single demand feeder was used for each tank at both sites, and nylon netting was used to deter aerial predators. During the fifth month of growth the feeding regime changed for the plastic tanks. Initially a two day supply was placed into the feeders by measuring the recommended amount of feed needed for the estimated trout biomass in each tank. In an attempt to reduce the odor of the fish feed that was believed to draw the local black bears into the research area at night, a one day ration was placed into each feeder well before sunset. This provided each tank with the same amount of daily feed without leaving feed in the feeders overnight.

Businesses that specialize in building concrete tanks provided recent quotes for the concrete tank cost estimate. The annual labor cost for cleaning the plastic and concrete tanks was determined by using an average of five cleanings taken over the last five months of the study. 
Although this study is not addressing environmental impacts of the systems involved, protocols developed by Plafkin et al. were used to determine the diversity of benthic macroinvertebrates in the stream (Hopkins Fork) that receives the discharge water from the plastic raceway system. A standard D-net was used to collect macroinvertebrates from five kick samples in Hopkins Fork.

History, maturation, differential selection, and instrumentation threats to validity were controlled by the research design. Although every effort was made to control external threats to validity, the black bear interest in the trout feed where the plastic tanks were located resulted in a modification of the manner in which the feed was presented to the trout in the plastic tanks. In an effort to reduce the odor of the fish feed, the feeders over the plastic tanks were filled daily. This gave the trout in the plastic tanks less access to feed and undoubtedly a stressful environment when the bears were competing with the trout for access to the feed.

\section{Data Collection Procedures}

In order to determine the chemical differences between the two water sources, ionic analysis was conducted at the beginning, in the middle, and at the end of the production cycle. Nitric acid was added to all cation samples to avoid any post-sampling changes. Both anion and cation samples were held on ice in plastic containers and sent directly to a lab for analysis. A certified laboratory using standard methods was used for all water analysis.

Growth data were collected every six weeks from a random sample of at least 50 fish from both systems using an Ohaus bench scale. The trout were crowded in each tank before multiple dip nets were used for random sampling. As the trout approached 
marketable size, fin condition was recorded using a scale from 0 (perfect) to $5(>90 \%$ missing or eroded) for each of the 7 rayed fins. This meant that each fish had a potential score of between 0 and 35. A photographic key, developed by Hoyle et al. (2007), for each of the fins, was used as a reference during the fin condition data collection.

Water quality was monitored in the plastic tanks using a YSI 600XLM sonde that recorded temperature, $\mathrm{pH}$, oxygen and conductivity every hour. A YSI oxygen meter was used for temperature and oxygen readings from the concrete system. A certified analytical laboratory analyzed water samples from both sites for anions and cations in order to compare any parameters that were outside the accepted range for growing rainbow trout.

In a simple raceway production system, dissolved oxygen is supplied by the amount of water flowing through the system. This was the case for both the concrete and plastic tanks. Water flow estimates can be made using a variety of weirs. Both production sites measured the water flow through the system on a regular basis using a MarshMcBirney Model 2000 portable flow meter.

Analysis of Data

An average weight was determined every six weeks for each random growth sample of at least 50 fish collected from the two sites. Standard deviation was calculated to show the variation in the sample size. The fin condition data were subjected to an analysis of variance (ANOVA) procedure.

The comparative cost of each ten tank system (precast concrete, poured concrete, and plastic) included the cost of site preparation, installation, and fencing. The least costly system was compared as a percentage of the most costly system. 


\section{Use of Findings}

The biological data are limited to applications where the water quality parameters are similar to those measured during data collection at both sites. More importantly the economic data can be applied to virtually any situation where the water flow is adequate (50 to 300 gallons per minute) for the 2000 gallon tanks. In effect this study is most useful to medium and small fish producers of any species. Larger operations can also utilize the economic data from this research if the tanks are used as a part of a larger operation. This could include using the tanks for quarantine, fry production, or pre-sale holding tanks for both indoor and outdoor use.

Efforts were made to program educational visits to the research site for demonstration purposes. Although this type of activity is not a specific objective of this research, it will contribute to the successful adoption of this new type of tank as a commercial product that can lower the investment cost for many different fish production operations. 


\section{CHAPTER IV}

\section{Findings}

\section{Purpose of the Study}

The purpose of this study was to compare the cost of construction, installation, waste collection, and quality of fish using a non-traditional material (high density polyethylene HDPE) in a nontraditional form ("U" shaped cross section) to the traditional concrete raceway system. The purpose was also to determine if the shape of the raceway could concentrate solid waste in a manner that will reduce the labor required to maintain a clean raceway system that will produce a high quality product.

Objectives of the Study

The objective of this research was to determine the cost of an alternative raceway material, including installation, and the ability of this material to commercially produce a high quality product. The following research questions directed this study.

1. How does the cost of HDPE material used for trout culture tanks, including the cost of construction, compare to industry standard concrete materials?

2. How does the waste collection and removal from the "U" shaped HDPE tanks compare to waste collection and removal from industry standard concrete raceways?

3. How does the fin condition of trout produced in HDPE tanks compare to trout produced at similar densities in concrete tanks?

4. Based on benthic macroinvertebrate collections, what was the stream condition index (macroinvertebrate biodiversity) of the receiving stream during the 
research? This will help determine if the level of trout production at this site is environmentally sustainable.

5. How does fish growth and mortality rates in HDPE tanks compare to trout produced at similar densities in concrete tanks?

\section{Results}

\section{Water Quality}

Numerous water quality parameters (cations and anions) were measured by a certified lab at three different times throughout the study to determine how similar the two water sources were to each other. Appalachian mine water is commonly found with high levels of calcium $(\mathrm{Ca})$, magnesium $(\mathrm{Mg})$, and sulfate $\left(\mathrm{SO}_{4}\right)$ ions compared to other groundwater sources. Although these three ion concentrations were significantly higher in the water source for the plastic tanks, the concentrations were well below other trout production water sources located in the region (Tierney 2002; Ashby \& Dean 2007) and therefore are not considered high enough to have a negative impact on the growth and survival of the trout.

The mine water source (plastic tanks) had the following results: $\mathrm{pH}$ : 7.26; SO4: 337 mg/l; Hardness: 464 mg/l; F: 0.09 mg/l; Cl: 5 mg/l; NO2: <0.03 mg/l; NO3: 1.06 mg/l; NH3: 0.02 mg/l; PO4: <0.15 mg/1; Al: <0.1 mg/l; Ca: 100 mg/l; Mg: 48 mg/l; Fe $<0.1 \mathrm{mg} / \mathrm{l} ; \mathrm{Mn}:<0.1 \mathrm{mg} / \mathrm{l} ; \mathrm{Zn}: 0.02 \mathrm{mg} / \mathrm{l}$ and conductivity: $925 \mathrm{uS} / \mathrm{cm}$. The well water for the concrete system had the following chemistry: pH: 6.67; SO4: $12.7 \mathrm{mg} / \mathrm{l}$; Hardness: $29.3 \mathrm{mg} / \mathrm{l} ; \mathrm{F}:<0.08 \mathrm{mg} / \mathrm{l} ; \mathrm{Cl}: 10.72 \mathrm{mg} / \mathrm{l} ; \mathrm{NO} 2:<0.03$; NO3: $0.57 \mathrm{mg} / \mathrm{l} ; \mathrm{NH} 3: 0.02 \mathrm{mg} / \mathrm{l}$; PO4: $<0.15 \mathrm{mg} / \mathrm{l} ; \mathrm{Al}:<0.1 \mathrm{mg} / \mathrm{l} ; \mathrm{Ca}: 6.04 \mathrm{mg} / \mathrm{l} ; \mathrm{Mg}: 2.52 \mathrm{mg} / \mathrm{l} ; \mathrm{Fe}:<0.1 \mathrm{mg} / \mathrm{l} ; \mathrm{Mn}:<0.1$ 
$\mathrm{mg} / \mathrm{l} ; \mathrm{Zn}:<0.1 \mathrm{mg} / \mathrm{l}$; TSS: $2 \mathrm{mg} / \mathrm{l}$; and conductivity: $134 \mathrm{uS} / \mathrm{cm}$. The results from the analysis are listed in Table 1.

Critical water quality parameters remained stable at both sites for the majority of this study. Water temperatures remained between 10 and 15 degrees Celsius at both sites. Water flow was a constant 100 gallons per minute in the concrete tank as it was pumped water. The gravity flow mine water was measured weekly and remained between 80 and 150 gallons per minute. The higher flows correlated with the increased biomass in the tanks during the latter part of the research to keep oxygen from becoming a limiting factor in growth.

Water chemistry analysis from both sites showed that all measured parameters were within the tolerance range of trout. The water quality monitoring that was done at each site showed that the concrete tank had one low oxygen event during the last week in May, which resulted in the precautionary removal of 400 trout (40\%) from the system. The plastic tanks had two low oxygen events in the lower tanks, one in May and one in June, due to the intrusion of a bear which managed to divert the water from the lower tanks. The upper two tanks were unaffected by this temporary diversion of water.

The mine water had much higher levels of conductivity, sulfate, and calcium. The overall impact of the higher levels of conductivity (dissolved ions) in the mine water may have helped to reduce stress, in the same way that salt is used to reduce stress when fish are handled or harvested. The iron reading of $0.23 \mathrm{mg} / \mathrm{l}$ from the plastic tanks is on the high end of tolerance for trout. Iron measurements were the same in all but one reading and there were no indications of any gill irritation at any time during the research. 
Table 1

Water Chemistry Data From the Two Water Sources.

\begin{tabular}{|c|c|c|c|c|c|c|c|}
\hline \multirow[b]{2}{*}{ Analyte } & \multirow[b]{2}{*}{ units } & \multicolumn{3}{|c|}{$\begin{array}{l}\text { Plastic } \\
\text { Dates }\end{array}$} & \multicolumn{3}{|c|}{$\begin{array}{c}\text { Concrete } \\
\text { Dates }\end{array}$} \\
\hline & & $12 / 14 / 06$ & $2 / 7 / 07$ & $6 / 13 / 07$ & $11 / 2 / 06$ & $2 / 26 / 07$ & $6 / 15 / 07$ \\
\hline $\mathrm{pH}$ & & & 7.26 & & & 6.67 & \\
\hline $\mathrm{SO} 4$ & $\mathrm{mg} / \mathrm{l}$ & 337 & 324 & 345 & 7.36 & 12.7 & 7.11 \\
\hline Hardness & $\mathrm{mg} / \mathrm{l}$ & & & 464 & & 29.3 & 20.54 \\
\hline $\mathrm{F}$ & $\mathrm{mg} / \mathrm{l}$ & $<.088$ & 0.092 & 0.093 & 0.13 & $<0.08$ & $<.008$ \\
\hline $\mathrm{Cl}$ & $\mathrm{mg} / 1$ & 2.9 & 5 & 5 & 10.72 & 10.77 & 10.16 \\
\hline NO2 & $\mathrm{mg} / \mathrm{l}$ & $<.03$ & $<.009$ & $<.009$ & $<0.03$ & $<.009$ & $<.009$ \\
\hline NO3 & $\mathrm{mg} / \mathrm{l}$ & 15.35 & 0.881 & 1.063 & 2.92 & 0.26 & 0.576 \\
\hline NH3 & $\mathrm{mg} / \mathrm{l}$ & & & 0.0233 & 0.0025 & & 0.02 \\
\hline PO4 & $\mathrm{mg} / \mathrm{l}$ & $<.158$ & $<.051$ & $<.051$ & $<.158$ & $<.051$ & 0.26 \\
\hline $\mathrm{Al}$ & $\mathrm{mg} / \mathrm{l}$ & $<.1$ & $<0.1$ & $<.1$ & $<.1$ & $<0.1$ & $<.1$ \\
\hline $\mathrm{Ca}$ & $\mathrm{mg} / \mathrm{l}$ & 100.19 & 83.16 & 104.68 & 6.04 & & 4.91 \\
\hline $\mathrm{Mg}$ & $\mathrm{mg} / \mathrm{l}$ & 50.47 & 42.38 & 48.55 & 2.52 & & 2.28 \\
\hline $\mathrm{Fe}$ & $\mathrm{mg} / \mathrm{l}$ & $<.1$ & 0.23 & $<.1$ & $<.1$ & & $<.1$ \\
\hline Mn & $\mathrm{mg} / \mathrm{l}$ & $<.1$ & $<.1$ & 0.14 & $<.1$ & & $<.1$ \\
\hline $\mathrm{Zn}$ & $\mathrm{mg} / \mathrm{l}$ & & & 0.021 & $<.1$ & & 0.016 \\
\hline TSS & $\mathrm{mg} / \mathrm{l}$ & & & & & 2 & \\
\hline Conduc. & $\mathrm{uS} / \mathrm{cm}$ & 925 & & & & 134 & \\
\hline
\end{tabular}




\section{Annual Maintenance / Cleaning Costs}

Assuming labor costs at $\$ 10 / \mathrm{hr}$. and cleaning occurs every five days (73 times per year), an average of five cleanings during the study resulted in 25 minutes per cleaning for nine plastic tanks. This translates into 3.4 hours per tank per year or $\$ 34 /$ tank/year. The concrete tank used a pump to remove the solids from the flat bottom. The average cleaning of the settling zone (four feet long by four feet wide) in this tank required 6.75 minutes. This translates into 8.2 hours per tank per year or $\$ 82 /$ tank/year. The purchase price for ten precast concrete, poured concrete, and plastic tanks was $\$ 45,850, \$ 33,110$, and $\$ 24,507$ respectively. Land preparation costs were $\$ 6,000, \$ 4,000$, and $\$ 3,000$ respectively. This resulted in a total cost including annual labor for cleaning of $\$ 52,670$ for the precast tanks, $\$ 37,930$ for the poured tanks and $\$ 27,811$ for the HDPE plastic tanks. When all variable and fixed costs are accounted for in the enterprise budget the cost per pound of production was $\$ 1.54$ for precast concrete, $\$ 1.42$ for poured concrete and $\$ 1.38$ for the plastic tanks (see Table 2 and Appendix A, B, and C).

Table 2

Cost Comparison for Concrete and Plastic Tank System (10 Tanks)

\begin{tabular}{lcccccc}
\hline & Cost (\$) & Install & Cleaning & Total Cost $(\$)$ & Cost / lb. & $\%$ precast \\
\hline Concrete precast & 45,850 & 6,000 & 820 & 52,670 & $\$ 1.54$ & $100 \%$ \\
Concrete poured & 33,110 & 4,000 & 820 & 37,930 & $\$ 1.42$ & $72 \%$ \\
HDPE plastic & 24,507 & 3,000 & 304 & 27,811 & $\$ 1.38$ & $53 \%$ \\
\hline
\end{tabular}

An economical analysis that can help to determine the discounted value of a long term investment is called net present value (NPV). A higher number indicates a better 
investment over the given time period. For a ten year investment time frame, using a 10 percent interest rate, for a farm producing 20,000 pounds per year, the NPV for precast concrete tanks was $\$ 52,326$. Under the same conditions the poured concrete tanks had a NPV of $\$ 53,892$. The plastic tanks had a net present value of $\$ 82,980$ over the same period. Changing the interest rate to $7 \%$ or $13 \%$ resulted in higher and lower numbers for each of the systems. In each case the plastic tanks had the more desirable result (see Table 3). The numbers in Table 2 represent a 10 tank system which would produce at least 14,000 pounds per year. The 20,000 pound annual production used in Table 3 was chosen for the round production level (20,000 lbs.) from 14 tanks.

Table 3

Net Present Value Over 10 Years for a 20,000 lb. / year Fish Farm

\begin{tabular}{cccc}
\hline Cost of Capital & $\begin{array}{c}\text { Net Present Value } \\
\text { Precast Concrete }\end{array}$ & $\begin{array}{c}\text { Net Present Value } \\
\text { Poured Concrete }\end{array}$ & $\begin{array}{c}\text { Net Present Value } \\
\text { Plastic Tanks }\end{array}$ \\
\hline $7 \%$ & $\$ 72,543$ & $\$ 71,472$ & $\$ 103,005$ \\
$10 \%$ & $\$ 52,326$ & $\$ 53,892$ & $\$ 82,980$ \\
$13 \%$ & $\$ 35,803$ & $\$ 39,524$ & $\$ 66,641$ \\
\hline
\end{tabular}

Internal rate of return (IRR) is another economical measurement that determines the compound interest rate of the investment over a given period of time. For a ten year investment outlook, the IRR for a farm producing 20,000 pounds per year using the precast concrete, poured concrete, and plastic tanks resulted in 23\%, 26\% and 36\% respectively (see Table 4). The higher percentages represent a more desirable or profitable investment. 
Table 4

Internal Rate of Return for a 20,000 lb. / year Fish Farm

\begin{tabular}{|l|c|}
\hline Time Period & Internal Rate of Return \\
\hline & Plastic $36 \%$ \\
10 years & Poured Concrete $26 \%$ \\
& Precast Concrete $23 \%$ \\
\hline
\end{tabular}

Growth

Growth, fin condition, and mortality data are presented based on the average of the top two plastic tanks compared to the concrete tank. This reduces the potential impact of poorer water quality (increased ammonia, increased solids, and reduced oxygen) in the lower tanks in the system. After 30 weeks the final weights were averaged from a random sample of at least 50 fish from the approximately 1000 fish stocked in each tank. Because the trout weighed nearly one pound and were ready for market, weights and lengths were taken to determine the standard deviation of length as well as the condition factor. The condition factor $(\mathrm{K})$ is determined using the following metric formula: average weight in grams divided by the average length in centimeters, cubed, or $\mathrm{K}=\left(\mathrm{W}_{\mathrm{g}}\right) / \mathrm{L}_{\mathrm{cm}}^{3}$. The trout in the concrete tank showed faster growth yet had a higher mortality (growth: 2.20 gm / day; mortality: 5.62\%) than those in the plastic tanks (growth: 1.75 gm./day; mortality: 4.83\%). The standard deviation in length was greatest at this point, and resulted in 2.73 in the concrete system and 2.15 in the plastic system. Fin condition was measured during this final day of data collection resulting in a composite average of 7.93 for trout in the concrete system, and 8.08 for trout in the plastic tanks (see Table 5). 
Table 5

Growth, Condition Factor, Mortality and Fin Condition from Concrete and Plastic Tanks

\begin{tabular}{|c|c|c|c|c|c|c|}
\hline & $\begin{array}{c}\text { volume } \\
\left(\mathrm{m}^{3}\right)\end{array}$ & $\begin{array}{c}\text { Growth rate } \\
\text { Gm / day }\end{array}$ & $\begin{array}{c}\text { Standard } \\
\text { deviation } \\
\text { (length) }\end{array}$ & $\begin{array}{l}\text { Condition } \\
\text { Factor } \\
\text { (metric) }\end{array}$ & $\begin{array}{c}\% \\
\text { mortality }\end{array}$ & $\begin{array}{c}\text { Fin } \\
\text { Condition }\end{array}$ \\
\hline Concrete & 7.84 & 2.20 & 2.73 & 0.0142 & 5.62 & $7.93 *$ \\
\hline Plastic & 7.57 & 1.75 & 2.15 & 0.0134 & 4.83 & $8.08 *$ \\
\hline
\end{tabular}

Fin Condition

The null hypothesis states that there is no difference in fin condition between the two populations of trout. A one way ANOVA was performed on the means of both groups' fin condition data using total scores to test the null hypothesis that there was no difference in the fin condition. When the trout from the two plastic tanks were compared to the trout in the concrete tank, the ANOVA procedure showed there was no significant difference $(\alpha<0.05)$ of fin erosion comparing the two trout populations, therefore we failed to reject the null hypothesis.

Mortality

Concerning mortality, the null hypothesis states that there is no difference in mortality between the two populations of trout. Results showed that mortality was higher in the concrete tank compared to the plastic tanks, therefore the null hypothesis was rejected. The mortality was not as simple as the data may indicate. The intrusion of the black bears at the site of the plastic tanks resulted in many "jumpers" that were found along the side of the tanks. Assigning these jumpers to a tank was based on where the fish were found along with evidence of tampering at an individual tank or the feeder above it. 
There is no doubt that the mortalities of the plastic tanks would have been much lower if the bears would have been excluded from the research tank area.

The initial number of trout stocked into each of the plastic tanks varied between 1,036 to a maximum of 1,095 . The concrete tank received 1015 trout, of which 57 died during the 220 days of production, resulting in a mortality rate of $5.62 \%$. The variation of mortality in the nine plastic tanks was dependant on the feeding location of the bears during the 209 days of production. Mortality in tanks five and six were most impacted by the bears (see Table 6). Average mortality in the nine plastic tanks was $4.83 \%$.

Table 6

Mortality Data From Individual Tanks

\begin{tabular}{lccccc}
\hline Tanks & Initial & Mortality & \% Mortality & No. of days & Ending date \\
\hline Concrete & 1015 & 57 & 5.62 & 220 & $6 / 15 / 2007$ \\
\hline Plastic 1 & 1074 & 49 & 4.56 & 209 & $6 / 13 / 2007$ \\
Plastic 2 & 1072 & 36 & 3.36 & 209 & $6 / 13 / 2007$ \\
Plastic 3 & 1036 & 17 & 1.64 & 209 & $6 / 13 / 2007$ \\
Plastic 4 & 1040 & 21 & 2.02 & 209 & $6 / 13 / 2007$ \\
Plastic 5 & 1040 & $123^{*}$ & 11.83 & 209 & $6 / 13 / 2007$ \\
Plastic 6 & 1095 & $118^{*}$ & 10.78 & 209 & $6 / 13 / 2007$ \\
Plastic 7 & 1088 & 37 & 3.40 & 209 & $6 / 13 / 2007$ \\
Plastic 8 & 1095 & 41 & 3.74 & 209 & $6 / 13 / 2007$ \\
Plastic 9 & 1074 & 22 & 2.05 & 206 & $6 / 10 / 2007$ \\
Plastic totals & 9614 & 464 & 4.83 \\
\hline \multicolumn{5}{c}{ * exaggerated mortality due to black bears }
\end{tabular}

If the two tanks that showed elevated mortalities due to the black bear intrusions (tanks 5 and 6) were to be excluded from the average of $4.83 \%$ the new seven tank average would be $2.98 \%$ which is nearly half of the $5.62 \%$ from the concrete tank. There were jumpers from every tank. It is impossible to determine the cause of every trout that jumped from the tank. The freeboard (the height from the water surface to the top of the 
tank) in the concrete tank varied from 8 to 13 inches. The freeboard in the plastic tanks varied from 1 to six inches. If the freeboard in the plastic tanks would have been the same as the freeboard in the concrete tanks, the mortalities in the plastic may have been even lower.

\section{Stream Condition}

During the sixth month of research (April 2007) a stream macroinvertebrate bioassessment was conducted in Hopkins Fork 100 meters below the discharge of the settling pond that collected the solid waste from the plastic tanks. A standard D-net was used to collect macroinvertebrates from 5 kick samples in Hopkins Fork. Benthic macroinvertebrates are good indicators of localized stream conditions because the bugs have limited migration patterns and this relatively simple and inexpensive procedure has shown to be well-suited for assessing impacts that are site-specific. Table 7 shows the results from the benthic collection with each invertebrate identified by Family. The trophic feeding level is indicated for each Family and the total number of bugs collected in each Family are listed along with the total number of bugs collected in the 5 kick sample. The classification resulted in twelve Families within seven Orders for a total of 541 bugs. Nearly $49 \%$ of those bugs were Caddisflies (Trichopterans), another $45 \%$ were Stoneflies (Plecopterans) both of which are generally considered to be intolerant to pollution. 
Table 7

Benthic Macroinvertebrates Collected From Hopkins Fork - Spring 2007

\begin{tabular}{lllc}
\hline Order & \multicolumn{1}{c}{ Family } & Trophic Level & Number \\
\hline Ephemeroptera & Ephimerillidae & Gatherer/Collector & 2 \\
Plecoptera & Nemouridae & Shredder & 241 \\
& Peltoperlidae & Predator & 2 \\
Trichoptera & Hydropsychidae & Filterer/Collector & 255 \\
& Polycentropodidae & Filterer/Collector & 2 \\
& Rhyacophilidae & Predator & 9 \\
Megaloptera & Corydalidae & Predator & 3 \\
Diptera & Simulidae & Gatherer/Collector & 2 \\
& Tipulidae & Shredder & 8 \\
& Chironomidae & Gatherer/Collector & 10 \\
CLASS: Oligochaeta & ?? & Gatherer/Collector & 5 \\
Decapoda & Cambaridae & Scraper & 2 \\
\hline
\end{tabular}

The West Virginia stream condition index (WVSCI) (Tetra Tech, 2000) provides a numerical rating to quantify the quality of a stream. A score of less than 55 is rated "poor", 55 to 69.9 is considered "marginal", a score of 70 to 85 is labeled "good" and anything above 85 is considered "excellent". The WVSCI for this sample resulted in a value of 78, which is a "good" (70-85) rating. Although this is only a snapshot of the conditions below the polishing pond, the presence of various families that are relatively 
pollution intolerant indicate that the level of trout production is not seriously degrading the receiving stream. To provide some reference to the sample taken during the research, during the previous year (2006) a stream sample was taken from the same place in the same stream using the same methods. The resulting WVSCI value of 81 can also be classified as a "good" rating. This would support the idea that the environmental impact of the research was not measurable using benthic macroinvertebrate protocols. 


\section{CHAPTER V \\ Discussion and Conclusion}

\section{Purpose of the Study}

The purpose of this study was to compare the cost of construction, installation, waste collection, growth, and quality of fish using a non-traditional material, high density polyethylene (HDPE) in a nontraditional form ("U" shaped cross section) to the traditional concrete raceway system. The purpose was also to determine if the shape of the raceway could concentrate solid waste in a manner that will reduce the labor required to maintain a clean raceway system that will produce a high quality product.

Objectives of the Study

The objective of this research was to determine the cost of an alternative raceway material, including installation, and the ability of this material to commercially produce a high quality product. The following research questions directed this study.

1. How does the cost of HDPE material used for trout culture tanks, including the cost of construction, compare to industry standard concrete materials?

2. How does the waste collection and removal from the "U" shaped HDPE tanks compare to waste collection and removal from industry standard concrete raceways?

3. How does the fin condition of trout produced in HDPE tanks compare to trout produced at similar densities in concrete tanks?

4. Based on benthic macroinvertebrate collections, what was the stream condition index (macroinvertebrate biodiversity) of the receiving stream during the 
research? This will help determine if the level of trout production at this site is environmentally sustainable.

5. How does fish growth and mortality rates in HDPE tanks compare to trout produced at similar densities in concrete tanks?

\section{Discussion}

It is possible that environmental impacts may be reduced by promoting multiple smaller fish farms dispersed throughout a region, versus a single large farm producing the same amount as all of the smaller farms. Water resources in West Virginia lend themselves to this dispersed type of production. The smaller farms are more likely to adapt to the regulatory restraints that are increasingly causing the large fish hatcheries to modify their production practices to reduce the environmental impacts caused by nutrient and solid waste originating from a point source.

Of the top ten states based on the value of aquaculture products most of them have succeeded by delegating the Department of Agriculture to be the lead organization to advise and inform prospective fish farmers about the requirements for commercial production of fish in their states. Nearly all of them have regulations that allow land application of aquaculture solid waste, provided that best management practices are being employed.

West Virginia has not designated a lead agency for aquaculture issues. The regulations dealing with aquaculture are not easy to find because they are scattered within many different organizations. Until the rules clearly indicate that aquaculture and nutrients from fish farms are classified as agriculture rather than industrial waste, which cannot be land applied, the industry will remain underdeveloped. 
If the plastic tanks have a shorter life span then concrete tanks, then the depreciation costs would be higher for the plastic tanks. The HDPE material is extremely resistant to weathering and it is expected that a properly installed tank, with welded strips on each side to protect the open ribs, will last as long as concrete tanks. New York State's Department of Transportation has rated the service life of HDPE pipe at 70 years, equal to that of reinforced concrete products. With proper installation it seems reasonable to assume the HDPE tank will have a service life of 20 years, as indicated in Table 8, equal to concrete that is exposed to freezing conditions.

The trout in the concrete tank had a faster growth rate than the trout in the plastic tanks. The difference in growth rate was likely due to the increased stress due to the predator problem. In an effort to reduce the smell of fish feed, which was drawing the bears to the site, daily hand feeding began on April $26^{\text {th }}$. Prior to that, feed was placed in the demand feeders every other day and the caretaker noted if the feeder was empty. The concrete system did not have a predator problem and the demand feeder was checked on a daily basis. This resulted in improved access to trout feed in the feeder. The effect of stress on trout can result in reduced growth rates.

The waste removal system for the plastic tanks was faster than in the concrete tank because it does not require siphoning or pumping of the solid waste from the production tank. Taking advantage of the "U" shape and the smooth plastic material, an 18 inch squeegee was used to move the solid waste toward the three inch manifold pipe that ran along the lowest portion of the settling zone. The $3 / 4$ inch openings in the pipe allowed the accumulated solids to exit through the pipe, due to hydrostatic (head) pressure from water in the tank, when an external valve was opened. This process 
avoided siphoning and pumping, a routine labor expense common to all flat bottomed concrete tanks. The cost of the plastic tank system included the three inch valve and the manifold pipe for solids removal.

The difference in solid waste removal, as described, resulted in lower labor costs for the plastic tank system. There is however an inherent added risk that is not found with the pumping or siphon waste removal system used in concrete tanks. The risk is that the caretaker may forget to shut the valve that removes the solids from the bottom of the tank. A comparison table was developed to clarify the various strengths and weaknesses of the two tank materials (Table 8).

Table 8

Comparisons Between Concrete and Plastic (HDPE) Fish Tanks

\begin{tabular}{lll}
\hline CONSIDERATIONS & CONCRETE & PLASTIC (HDPE) \\
\hline Purchase Cost & Higher & Lower \\
Tank weight & $36,000 \mathrm{lbs}$. & $760 \mathrm{lbs}$. \\
Site Prep. Cost & Higher & Lower \\
Vulnerability & Low & Moderate \\
Installation & Critical & Critical \\
Easily Modified & No & Yes \\
Useful Life & 20 years & 20 years?? \\
Waste Removal & Slower & Faster \\
Flexibility & None & Little \\
Production volume & 2000 gallons & 2000 gallons \\
Size restrictions & Customized & Max. 60 inch diameter \\
Outside use & No restrictions & Recommended 20” in ground \\
Inside use & No restrictions & HDPE cross supports \\
Resale or Transfer & More difficult & Less difficult \\
\hline
\end{tabular}




\section{Conclusions}

From November until May the water quality remained within the accepted parameters for trout at both of the sites. Growth and survival were normal for the plastic tanks until the intrusion of black bears became in issue. The bear intrusion caused the trout in the plastic tanks to jump out of the tank which made it difficult to determine which tank they originated from. The fish feed appeared to be the bear's target as many feeders were found strewn about the site, some needing repairs. Efforts to repair the fence were unsuccessful as a corner pole set in concrete was eventually bent over and the concrete base was shattered. On May $1^{\text {st }}$ a 250 pound male black bear was trapped and removed from the area. Two nights later another bear had breached the fence.

The purchase price of the plastic tanks was lowest, costing only $53 \%$ of the precast tank system. Installation of the plastic tanks was also lower due to a lack of need for heavy machinery required by the precast tanks. The poured tanks required rental of a concrete pump, on the recommendation of two concrete contractors, for pouring the walls. The land preparation for the plastic tanks was slightly less than the flat bottomed concrete tanks because the plastic tanks require a narrower leveled pad due to the "U" shaped nature of the tank.

The waste collection effort was minimized with the plastic tanks due to the manner in which the solids settled around the manifold in the "U" shaped cross section. The measured time for cleaning the plastic tank was less than half the time it took to clean the concrete tank. This will result in considerable savings over the life span of the tank. 
The fin condition of trout from both plastic and concrete tanks were similar. The dorsal fin was the most damaged of the seven rayed fins, and it is least likely to be impacted by the tank material. Both populations had relatively healthy complete fins.

Based on the benthic macroinvertebrate collections 100 meters from the pond discharge, the stream condition index (WVSCI) resulted in a value of 78 , which is a "good" rating. If this rating remains the same over the years, at the present production level, it could be argued that the production is being done in an environmentally sustainable manner.

The growth and mortality results from both plastic and concrete tanks were typical results from commercial trout operations. Although growth was slightly better in the concrete system, the mortality was slightly higher than in the plastic tanks. The measurable differences do not necessarily mean that they were due to the material in which the trout were grown. Due to the external threat to validity (black bear intrusions) as far as growth and survival is concerned, it cannot be concluded that either material had an advantage over the other based on the results from this research.

\section{Use of Findings}

The results of the research may be useful for small to medium sized producers, due to the limited size of the plastic raceway, if the tank is used for growout. Larger operations can use the tank for larval rearing, fingerling production, quarantine or holding tanks for harvest. Because this tank is so easily modified to accommodate recirculating systems, either indoors or outdoors, the costs will change only slightly depending on the additional cost of biofiltration and solids filtration, both of which can easily be incorporated within the confines of the tank itself. 
This information will be made available to the public through multiple sources. The funding sources include the Northeast Regional Aquaculture Center (NRAC), West Virginia University (WVU), and Eastern Coal Company. Each of these stakeholders will be given electronic and hard copies of the results. NRAC and WVU have web sites that include aquaculture research results that are updated to allow fish producers to be informed of the latest innovations in the industry.

\section{Recommendations and Implications}

Any new product needs to be adopted by a few innovative people in order to find its' place in the commercial market. In an effort to make this new tank available to a wider audience, a model tank has been manufactured and sent to the world's largest supplier of aquaculture products. They will carry the model to various trade shows to get feedback from potential customers. Although the 30 foot tank is limited to approximately 2000 gallons of capacity, longer tanks can be custom made. By using a simple airlift this tank design can be converted into a recirculating holding tank.

It would be useful to continue to collect production data from the experimental tanks. This data would also be used to determine how the freezing conditions impact the longevity of the tank. A study comparing growth, survival and fin condition in plastic and concrete tanks using the same water source is recommended. Finding an indoor user would help with determining the proper spacing between cross bars used for support.

The accessories for this new tank such as screens and graders, which are used routinely in commercial operations, will need to be improved over the prototype used in this research. Specifically, the screens will need to be weighted down more, for negative buoyancy, to avoid floating out of place. Strengthening the connection between the 
screen material and the screen frame will reduce the chance of screen failure when crowding the fish for sampling or harvest. All of these details can be accomplished inexpensively by working with the early adopters of this new product.

West Virginia University has received a provisional patent on this tank. Obtaining approval from the United States Patent Office is a timely process. In May 2007, a Supreme Court ruling on a patent case has made it more difficult to get patents issued where all of the features are individually represented in various other references even when the references are not in the same field of invention. A patent search has shown a number of patents awarded to persons that have one or two similarities to this invention. The real test of patentability is what the prior art teaches (previously awarded patents) compared to the claims in the patent application. It is unclear at this time if the new tank has enough unique advantages to be awarded a U.S. patent. 


\section{REFERENCES}

Ashby J.C. \& Dean, J.M. (n.d.). Treated mine drainage effluent benefits Maryland and West Virginia fishermen. Retrieved November 14, 2007 from http://www.gcnet.net/mettiki/extra2.html

Barbour, M.T., Gerritsen, J., Snyder, B.D., \& Stribling, J.B. (1999). Rapid bioassessment protocols for use in streams and wadeable rivers: Periphyton, benthic macroinvertebrates and fish, (2ed Ed.). EPA 841-B-99-002. U.S. Environmental Protection Agency; Office of Water; Washington, D.C.

Bender, T., Lukens, W., \& Ricker, D. (1999). Feed conversion, growth, and deposition of solid waste when production of rainbow trout were fed three commercially available salmonid diets over a five month period at the Benner Spring Fish Research Station. Pennsylvania Fish and Boat Commission, Benner Spring Fish Research Station, 1225 Shiloh Road, State College, PA 16801.

Bergheim, A., \& Cripps, S. (1998). Effluent management: Overview of the European experience ( $\mathrm{pp}$.233-245). Proceedings of The Second International Conference on Recirculating Aquaculture. July 16-19, 1998. Roanoke, Virginia.

Boardman, G., Maillard, V., Nyland, J., Flick, G., \& Libey, G. (1998). Final report: The characterization, treatment and improvement of aquacultural effluents. Virginia Department of Environmental Quality, 629 East Main Street, Richmond, VA 23219

Boone, E.J., Safrit, R.D., \& Jones, J. (2002). Developing Programs in Adult Education, (2ed Ed.) Prospect Heights, IL. Waveland Press, Inc. (ISBN 1-57766-229-6)

Bosakowski, T., \& Wagner, E.J., (1995). Experimental use of cobble substrates in concrete raceways for improving fin condition of cutthroat (Oncorhynchus clarki) and rainbow trout (Oncorhynchus mykiss). Aquaculture 130, 159-165.

Caffarella, R.S. (2002). Planning Programs for Adult Learners, (2ed Ed.) San Francisco, CA. Jossey-Bass Publishers. (ISBN 0-7879-5225-7)

Ewart, J., Hankins, J., \& Bullock, D. (1995). State policies for aquaculture effluents and solid wastes in the northeast region. Northeast Regional Aquaculture Center (NRAC) Bulletin No. 300; University of Dartmouth, Massachusetts 02747

Flemlin, G.; Sugiura, S.; \& Ferraris, R.P. (2003). Examining phosphorus in effluents from rainbow trout (Oncorhynchus mykiss) aquaculture. Rutgers Cooperative Extension, New Jersey Agricultural Experiment Station, Bulletin E287. 
Hulbert, P.J. (2000). Phosphorus reductions at Adirondack Hatchery: Is the end in sight? Proceedings: Third East Coast Trout Management and Culture Workshop. June 6-8, 2000 Frostburg State University, Frostburg, MD.

Hoyle, I., Oidtmann, B., Ellis, T., Turnbull, J.F., North, B., Nikolaidis, J., \& Knowles, T.G. (2007). A validated macroscopic key to assess fin damage in farmed rainbow trout (Oncorhynchus mykiss) . Aquaculture 270 (1), 142-148.

Idaho Waste Management Guidelines for Aquaculture Operations (1997). Division of Environmental Quality, State of Idaho.

Jenkins, M.R., Wade, E.M., Fletcher, J.J., \& Hankins, J.A. (1995). Economic analysis of non-traditional water resources for aquaculture in West Virginia; The Conservation Fund's Freshwater Institute P.O. Box 1889 Shepherdstown, WV 25443

Kreutzweiser, D.P., Capell, S.S., and Good, K.P. (2005). Macroinvertebrate community responses to selection logging in riparian and upland areas of headwater catchments in a northern hardwood forest. Journal of the North American Benthological Society. 24, 208-222

Larmoyeux, J.D. \& Piper, R.G. (1971). A promising method of reducing eroded fin condition in hatchery trout. Am. Fish. U.S. Trout News. 16(3).

Loch, D., West, J., \& Perlmutter, D. (1996). The effect of trout farm effluent on the taxa richness of benthic macroinvertebrates. Aquaculture, 147, 37-55

Malmqvist, B. \& Hoffsten, P. (1999). Influence of drainage from old mine deposits on benthic macroinvertebrate communities in central Swedish streams. Water Research 33, 2415-2423

Mudrak, V.A. (1981). Guidelines for economical commercial fish hatchery wastewater treatment systems. Proceedings of the Bio-engineering Symposium for Fish Culture.

Mugg, J., Serrano, A., Liberti, A., \& Rice, M. (2000). Aquaculture effluents: A guide for water quality regulators and aquaculturists. Northeastern Regional Aquaculture Center (NRAC) Publication No. 00-003.

National Research Council (1993). Nutrient Requirements of Fish. National Academy Press, Washington, D.C.

The State of World fisheries and Aquaculture (2002). Food and Agriculture Organization of the United Nations. Rome, Italy. 
Naylor, S.J., Moccia, R.D., \& Durant, G.M. (1999). The chemical composition of settleable solid fish waste (manure) from commercial rainbow trout farms in Ontario, Canada. North American Journal of Aquaculture, 61(1), 21-26.

North, B.P., Turnbull, J.F., Ellis, T., Porter, M.J., Migaud, H., Bron, J. \& Bromage,N.R.,, (2006). The impact of stocking density on the welfare of rainbow trout (Oncorhynchus mykiss). Aquaculture 255, 466-479.

Petty, J. T., \& Barker, J. (2004). Water quality variability, trace metals, and implications for restoring a mined Appalachian watershed. Proceedings of the American Society of Mining and Reclamation, 21,1484-1504.

Petty, J. T. (2004). An ecological index to assess alternative regulation of thermal impact at the Albright Power Station, WV. Proceedings of the EPRI Thermal Ecology and Management Workshop. Date/page

Plafkin, J.L., Barbour, M.T., Porter, K.D., Gross, S.K., \& Hughes, R.M. (1989). Rapid bioassessment protocols for use in streams and rivers: Benthic macroinvertebrates and fish. U.S. Environmental Protection Agency, Office of Water Regulations and Standards, Washington D.C. EPA 440-4-89-001.

Sorensen, E.M. (1991). Metal poisoning in fish CRC Press, Boca Raton, Florida.

Summerfelt, S. T., Timmons, M.B., \& Watten B. J. (2000). Tank and raceway culture In R. R. Stickney (Ed.) Encyclopedia of aquaculture (pp. 921-928). John Wiley \& Sons, Inc., New York.

Summerfelt, S. T. (1997). Waste solids control in intensive aquaculture systems. Pg.2734. Aquacultural Engineering Society Workshop on Design of Aquaculture Systems and Processes, February 21, 1997 in Seattle WA.,

Tetra Tech (2000). A stream condition index for West Virginia Wadeable Streams. Prepared for U.S. EPA Region 3 Environmental Services Division by Tetra Tech, Inc. 10045 Red Run Blvd. Suite 110 Owings Mills, MD 21117 Web site: http://www.littlekanawha.com/536_WV-Index.pdf

Tierney, A.E. (2002). The technical feasibility of using treated mine water to rear rainbow trout, Oncorhynchus mykiss. Unpublished master's thesis - West Virginia University, Morgantown, W.Va.

Wagner, E.J., Intelmann, S.S., \& Routledge, M.D. (1996). The effects of fry rearing density on hatchery performance, fin condition, and agonistic behavior of rainbow trout Oncorhynchus mykiss fry. Journal of the World Aquaculture Society, 27(3). 
Wagner, E.J., Routledge, M.D., \& Intelmann, S.S. (1996). Fin condition and health profiles of albino rainbow trout reared in concrete raceways with and without a cobble substrate. The Progressive Fish-Culturist, 58(1) 38-42.

Westers, H. (2000). The case of Michigan's Platte River salmon hatchery - A fourteen year dispute about phosphorus effluent contribution and its impact on Platte Lake: A precedence for public fish hatcheries? Proceedings: Third East Coast Trout Management and Culture Workshop. Frostburg State University, Frostburg, MD.

Wholey, J. S., Hatry, H. P., \& Newcomer, K. E., (2004). Handbook of Practical Program Evaluation, (2ed Ed). San Francisco, CA. Jossey-Bass Publishers. (ISBN 07879-6713-0).

Wong, K.B.; \& Piedrahita, R.H. (2003). Solids removal from aquacultural raceways. World Aquaculture, 34(1).

Zeigler, T., \& Johnson, J.A. (1998). Trends in feed and feeding strategies. Proceedings of The Second International Conference on Recirculating Aquaculture. July 16-19, 1998, 229-232. 
APPENDICES 
APPENDIX A

Budget for: 20,000 pound per year trout farm - Concrete pre-cast tanks 
Enterprise Budget:

\begin{tabular}{|c|c|c|c|c|c|}
\hline Construction & Unit & $\begin{array}{c}\text { price (\$) } \\
\text { /unit }\end{array}$ & \# units & $\begin{array}{c}\text { Total } \\
\$ \\
\end{array}$ & \% Total \\
\hline Site Preparation & dollar & & & 6000 & $7 \%$ \\
\hline Water diversion & dollar & & & 500 & $1 \%$ \\
\hline Precast tank (2000 gallon) & tank & 4,585 & 14 & 64190 & $72 \%$ \\
\hline Emergency pump / pipe & & 1,100 & 1 & 1100 & $1 \%$ \\
\hline Screens (1 per tank) & each & 35 & 14 & 490 & $1 \%$ \\
\hline Chain link fence (option) & foot & 20 & 680 & 13600 & $15 \%$ \\
\hline Equipment sub-total & & & & 85880 & $97 \%$ \\
\hline Demand feeder (installed) & each & 200 & 14 & 2800 & $3 \%$ \\
\hline Net, gloves, boots & & & 1 & 250 & $0 \%$ \\
\hline sub-total & & & & 3050 & $3 \%$ \\
\hline Total initial investment & & & & 88930 & $100 \%$ \\
\hline
\end{tabular}

\begin{tabular}{|c|c|c|c|c|c|}
\hline Annual sales & Unit & $\begin{array}{l}\text { price (\$) } \\
\text { /unit }\end{array}$ & \# units & $\begin{array}{c}\text { Total } \\
\$\end{array}$ & \% Total \\
\hline Recreational market & lb. & 2.5 & 15,000 & 37500 & $83 \%$ \\
\hline Food market & lb. & 1.5 & 5,000 & 7500 & $17 \%$ \\
\hline Total Sales & lb. or dollar & & 20,000 & 45000 & $100 \%$ \\
\hline \multicolumn{6}{|l|}{ Variable Costs } \\
\hline fingerlings (3") & each & 0.21 & 14,000 & 2940 & $10 \%$ \\
\hline Feed $(\mathrm{FCR}=1.2: 1)$ & lb. & 0.4 & 24,000 & 9600 & $31 \%$ \\
\hline Electricity & month & 10 & 12 & 120 & $0 \%$ \\
\hline Labor (8 hours/week) & hour & 10 & 416 & 4160 & $13 \%$ \\
\hline Interest on operating capital & dollar & 0.1 & 16820 & 1682 & $5 \%$ \\
\hline Delivery Costs & mile & 0.5 & 1000 & 500 & $2 \%$ \\
\hline Total Variable costs & & & & 19002 & $62 \%$ \\
\hline \multicolumn{3}{|l|}{ Fixed Costs } & \multicolumn{3}{|c|}{$\$$} \\
\hline Interest on Ave. Ann. Inv. & percent & $10 \%$ & 44465 & 4447 & $14 \%$ \\
\hline Property taxes & percent & $2 \%$ & 88930 & 1779 & $6 \%$ \\
\hline Land lease & \$/month & 100 & 12 & 1200 & $4 \%$ \\
\hline Repairs and depreciation & percent & $5 \%$ & 88930 & 4447 & $14 \%$ \\
\hline Total Fixed Costs & & & & 11872 & $38 \%$ \\
\hline $\begin{array}{l}\text { Total Costs } \\
\text { Total cost / pound produced }\end{array}$ & & $\begin{array}{l}\quad 1.54 \\
\text { Returns to land } \\
\text { and op. mgmt. }\end{array}$ & & 30874 & $100 \%$ \\
\hline
\end{tabular}


APPENDIX B

Budget for: 20,000 pound per year trout farm - Concrete poured tanks 
Enterprise Budget:

\begin{tabular}{|c|c|c|c|c|c|}
\hline Construction & Unit & price (\$) /unit & \# units & $\begin{array}{c}\text { Total } \\
\$\end{array}$ & $\begin{array}{c}\% \\
\text { Total }\end{array}$ \\
\hline Site Preparation & dollar & & & 4000 & $6 \%$ \\
\hline Water diversion & dollar & & & 500 & $1 \%$ \\
\hline Concrete tank (2000 gallon) & tank & 3,311 & 14 & 46354 & $67 \%$ \\
\hline Emergency pump / pipe & & 1,100 & 1 & 1100 & $2 \%$ \\
\hline Screens (1 per tank) & each & 35 & 14 & 490 & $1 \%$ \\
\hline Chain link fence (option) & foot & 20 & 680 & 13600 & $20 \%$ \\
\hline \multicolumn{4}{|l|}{ sub-total } & \multicolumn{2}{|c|}{ Equipment } \\
\hline Demand feeder (installed) & each & 200 & 14 & 2800 & $4 \%$ \\
\hline Net, gloves, boots & & & 1 & 250 & $0 \%$ \\
\hline sub-total & & & & 3050 & $4 \%$ \\
\hline \multicolumn{4}{|l|}{ Total initial investment } & 69094 & $100 \%$ \\
\hline \multicolumn{3}{|l|}{ Annual sales } & \# units & $\begin{array}{c}\text { Total } \\
\$\end{array}$ & $\begin{array}{c}\% \\
\text { Total }\end{array}$ \\
\hline Recreational market & lb. & 2.5 & 15,000 & 37500 & $83 \%$ \\
\hline Food market & lb. & 1.5 & 5,000 & 7500 & $17 \%$ \\
\hline Total Sales & 1b. or dollar & & 20,000 & 45000 & $100 \%$ \\
\hline \multicolumn{6}{|l|}{ Variable Costs } \\
\hline fingerlings (3") & each & 0.21 & 14,000 & 2940 & $10 \%$ \\
\hline Feed $(\mathrm{FCR}=1.2: 1)$ & lb. & 0.4 & 24,000 & 9600 & $34 \%$ \\
\hline Electricity & month & 10 & 12 & 120 & $0 \%$ \\
\hline Labor (8 hours/week) & hour & 10 & 416 & 4160 & $15 \%$ \\
\hline Interest on operating capital & dollar & 0.1 & 16820 & 1682 & $6 \%$ \\
\hline Delivery Costs & mile & 0.5 & 1000 & 500 & $2 \%$ \\
\hline Total Variable costs & & & & 19002 & $67 \%$ \\
\hline \multicolumn{3}{|l|}{ Fixed Costs } & \multicolumn{3}{|c|}{$\$$} \\
\hline Interest on Ave. Ann. Inv. & percent & $10 \%$ & 34547 & 3455 & $12 \%$ \\
\hline Property taxes & percent & $2 \%$ & 69094 & 1382 & $5 \%$ \\
\hline Land lease & \$/month & 100 & 12 & 1200 & $4 \%$ \\
\hline Repairs and depreciation & percent & $5 \%$ & 69094 & 3455 & $12 \%$ \\
\hline Total Fixed Costs & & & & 9491 & $33 \%$ \\
\hline $\begin{array}{l}\text { Total Costs } \\
\text { Total cost / pound produced }\end{array}$ & & $\begin{array}{c}1.42 \\
\text { Returns to land and } \\
\text { op. mgmt. }\end{array}$ & & 28493 & $100 \%$ \\
\hline
\end{tabular}


APPENDIX C

Budget for: 20,000 pound per year trout farm - Plastic (HDPE) tanks 
Enterprise Budget:

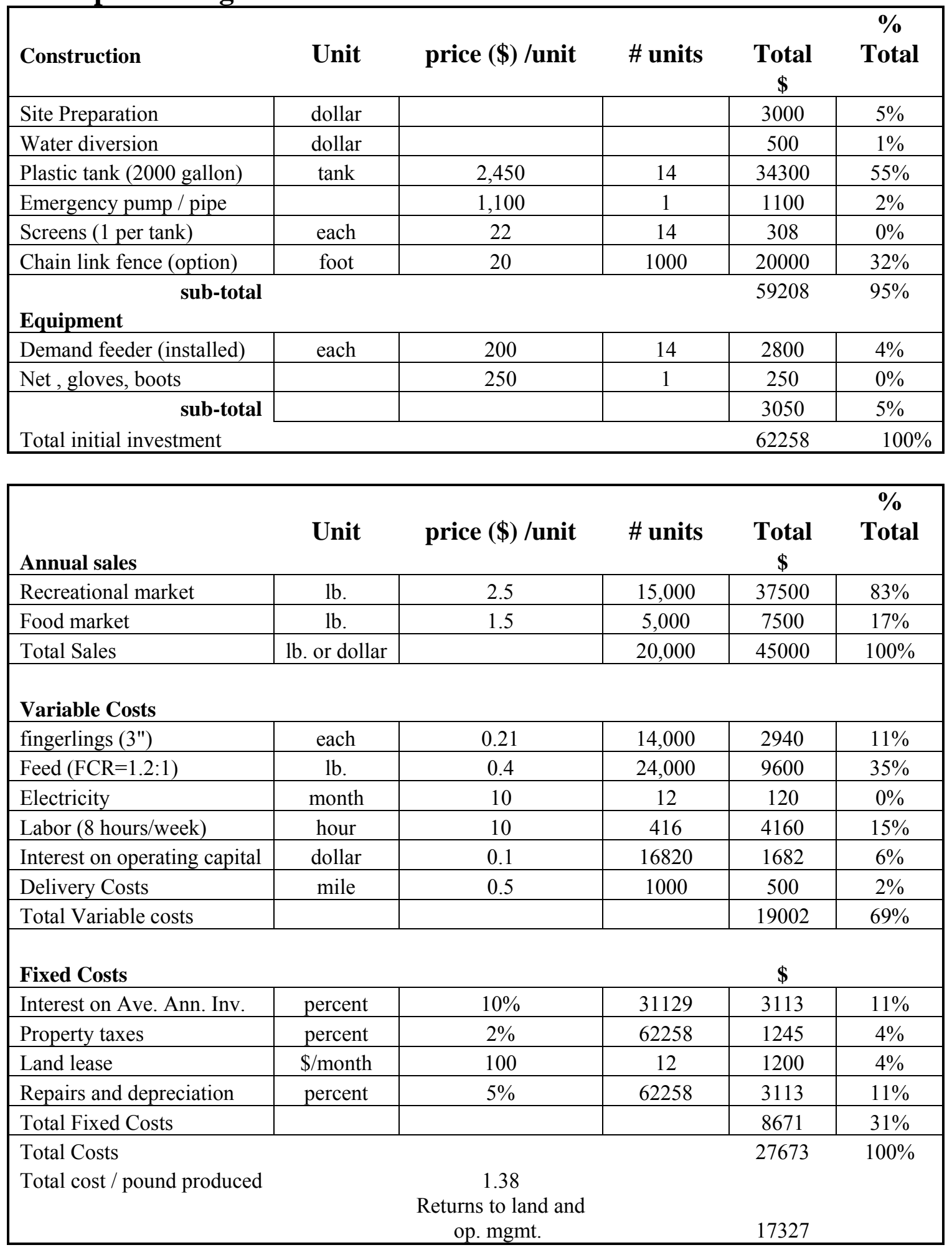


Production and Cost assumptions:

Ave. flow rate $=200 \mathrm{gpm}$; Average growth rate of $2.1 \mathrm{gms}$./day

48 weeks of production / tank / year $(5 \%$ mortality $)=1,476 \mathrm{lbs}$. production / tank / year.

Stocking rate: 1000 fingerlings per tank

Harvest size: 1.0 to $1.50 \mathrm{lbs}$.

Site preparation includes labor.

Serial use with 14 levels of production ( $3 \mathrm{ft}$. drop between tanks)

Concentration of un-ionized ammonia remains below $0.03 \mathrm{mg} / 1$

Chain Link Fence: 72" 9 guage galvanized 2" mesh (post every 10') 
APPENDIX D:

Photo of a model high density polyethylene (HDPE) tank. 


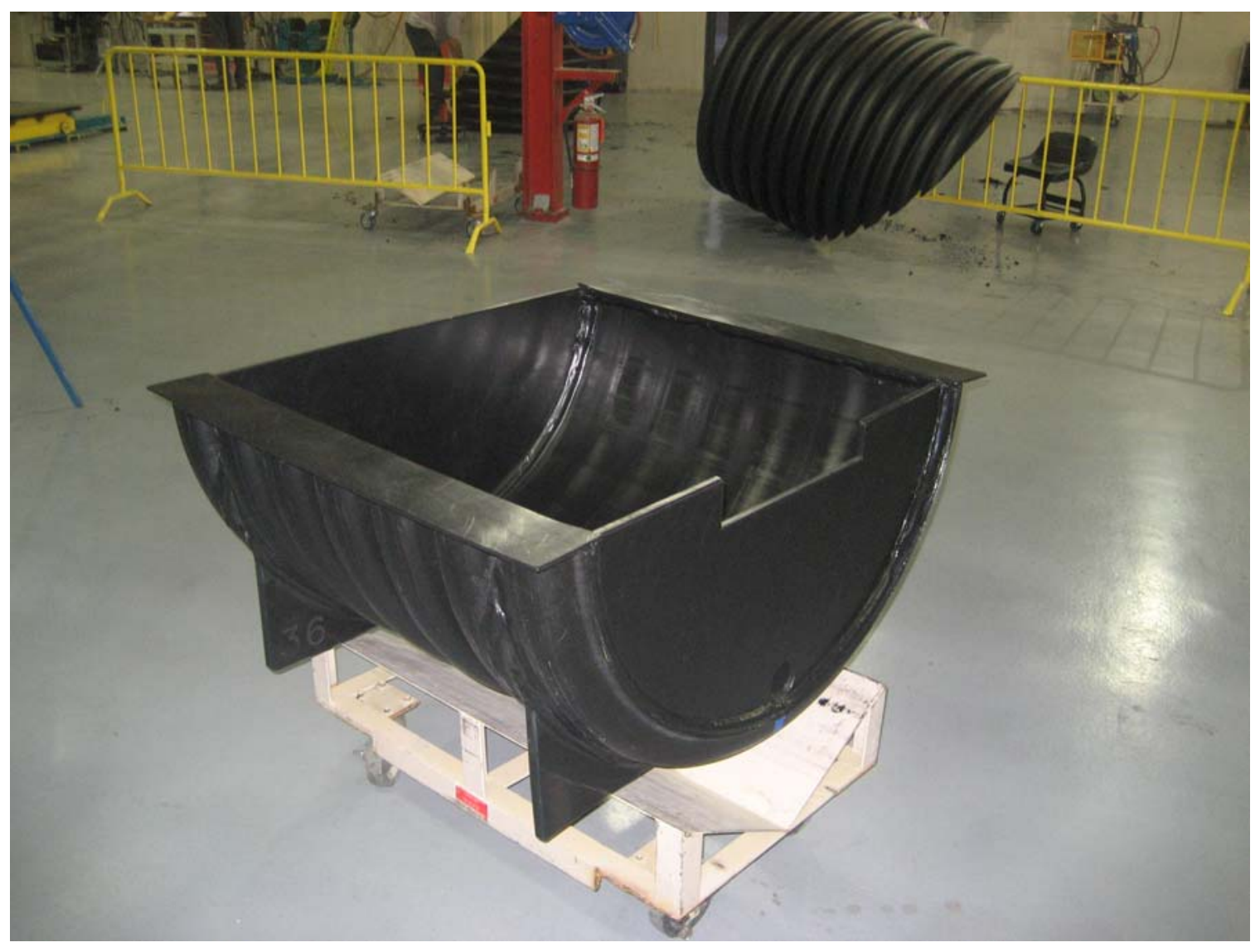

Figure 3: Model of a High density polypropelyne (HDPE) tank 
VITA

DANIEL J. MILLER

Home phone: 304-328-4379

Office: $304-293-4832 \times 4465$

e-mail: dmille31@,wvu.edu

WVU - Ag. Sci Bldg. Rm. 2026

Education: Ph.D. in Agricultural and Extension Education - WVU

Master of Aquaculture; Auburn University (3/87)

Bachelor of Science; Major: Zoology / Fisheries, Univ. of Wisconsin (6/81)

Languages: English and Spanish

Experience:

8/99 -Date Research Associate, (a faculty equivalent position)

West Virginia University Morgantown, WV

Instructor, Providing assistance in developing aquaculture to all stakeholders in the state of West Virginia. Identification of potential sites, creating and managing ArcInfo / GIS databases for presenting and analyzing information. Conducting demonstration projects and research to improve sustainability for fish farmers and disseminating the information to producers. Coordinating a cooperative approach to the development of state aquaculture.

3/94 -Date OWNER / MANAGER, AQUA DOC'S TROPICAL FISH INC. Morgantown, WV

Directing the company as a producer of aquatic products as well as a provider of technical information for companies involved in producing aquatic products. Services include: Water quality analysis, system design and management. Training of personnel for operations and disease diagnosis, using recirculation technology. Stream bioassessment.

Great Lakes Water Institute. 3/98-4/99 Design, set-up and training of personnel for a 10,000 gallon recirculating research unit for the University of Wisconsin- Milwaukee.

Red Lake Tribal Hatchery. 3/98-4/99. Planning, design, set-up, and training of personnel for a yellow perch recirculating grow-out facility at the Red Lake Tribal Hatchery in Red Lake, MN. Responsibilities included assembly, training of personnel and stocking the system with yellow perch.

ICASUR S.A., Aquacultura Fonseca, CODISUR S.A. Annual Visits: Providing technical assistance to marine shrimp farms and a tilapia farm in Honduras and Ecuador. 
High Tech Fisheries, $12 / 96-12 / 97$. Directed the management of a $95 \%$ recirculating freshwater ornamental fish hatchery. Disease was controlled by installation of ultra violet disinfection units in all three systems. Responsibilities also included spawning research on the Neon Tetra (Paracheirodo innesi).

AquaDoc's Tropical Fish Inc. 3/94-11/96 Spawning, production and marketing of ornamental fish and snails. Rehabilitation of an abandoned farm in Florida. Initially the farm was leased from the owner. Within two years a buyout was agreed upon and by the third year it was sold as a profitable operation.

9/89 - 9/92 ADMINISTRATIVE / PRODUCTION MGR, DELI GROUP SHRIMP CO. Guayaquil, Ecuador

Managed a group of companies, which employed 200 people, that exported shrimp to the U.S. and Europe. Directed operations for 1500 acres of marine shrimp pond production and 500 cubic meters of larval production. Approved expenses and directed research studies on shrimp and Redfish at laboratory and farm levels. Research was continuous yet secondary to production goals. Disease diagnosis was implemented and used as an integral part of management as the quality of the water in the Guayas estuary deteriorated. Programmed stocking, transfer, harvest, and exportation of shrimp. Exceeded 2 million pounds of production in final year (1992).

7/88-7/89 PRODUCTION MANAGER, GAMBALIT SHRIMP FARM, Guayaquil, Ecuador

Responsible for 500 acres of pond production, including hiring, evaluation and training of 50 personnel. Programmed pond preparation, stocking, transfer and harvest.

6/87-7/88 WATER QUALITY ANALYST, AMORIENT AQUACULTURE INT'L (Aquaspecies). Guayaquil, Ecuador

Contracted to analyze water quality, conduct experiments and train personnel for laboratory. Provided information on water quality parameters within the farm and the surrounding estuary. Initiated studies on aeration within the farm.

10/86-3/87 RESEARCH ASSISTANT, AUBURN UNIVERSITY RESEARCH STATION, Auburn, AL

Responsibilities included maintenance of water quality in catfish ponds, record keeping, stocking and harvesting. Disease diagnosis and treatment. Extension work. 
10/85-9/86 RESEARCH TECHNICIAN, COLLEGE OF THE VIRGIN ISLANDS RESEARCH STATION, St. Croix, United States Virgin Islands.

Performed water quality analysis and maintenance of recirculating hydroponic vegetable / tilapia production experiments. Developed site selection, planning, design, and construction of marine cage culture project.

9/84-5/85 RESEARCH ASSISTANT, AUBURN UNIVERSITY RESEARCH STATION, Auburn, AL

Responsibilities included maintenance of water quality in catfish ponds, record keeping, stocking and harvesting. Disease diagnosis and treatment. Extension work.

6/85-9/85 CONSULTANT, UNIVERSITY OF WISCONSIN, Milwaukee, WI Provided a report on hatchery expansion and operations; including hydrological survey, water source options, pond and tank design. Biological survey of existing pond with recommendations for improving water quality. The hatchery was constructed with minor changes from the initial report.

1/82-6/82 MARICULTURE LABORATORY ASSISTANT, ISRAELI OCEANOGRAPHIC AND LIMNOLOGICAL RESEARCH CO. Elat, Israel Assisted in the construction of sea rafts, cages and larval tanks; bioassayed sea bream and mullet gonads for hormone / reproduction experiments. Feeding and harvesting of sea bream in sea cages, and mullet in experimental ponds. Conducted a biological survey of an underwater reef area.

\section{2/78-5/81 RESEARCH ASSISTANT, GREAT LAKES RESEARCH FACILITY,} Milwaukee, WI

Duties included identification of developmental stages of embryo / larval sturgeon; field collections to determine condition of fish populations; collection and maintenance of native species.

\section{Publications:}

Miller, D., D'Souza, G., Conklin, C., (in press 2008) Using Aquaculture as a Post-Mining Land Use in West Virginia. Journal of International Mine Water Association.

Borisova, T., G. D’Souza, D. Miller, \& W. Labys. (2007) Remaining Competitive at the Regional level: $\quad$ Developing a Local Aquaculture Industry. J. Aquaculture Econ \& Mgmt 11: 73-98.

Borisova, T. P. Vantaram, G. D'Souza, D. Miller, \& C. Zabriski.

Web-Based Tool for Economic Analysis of Fish Transportation Decisions. World Aquaculture, 38(2007): 34-71.

Miller, D., Semmens, K., D'Souza, G. (2005) Trout Culture as a Post-Mining Land Use in West Virginia - A Case Study. Aquaculture America 2005 Abstracts. 
Miller, D., Semmens, K., Viadero, R., and Tierney, A. (2004) The resource potential of mining discharge water for aquaculture. World Aquaculture: Vol.35 No. 4 pp.5770 .

D’Souza, G., D. Miller, K. Semmens and D. Smith. (2004) Mine Water Aquaculture as an Economic Development Strategy: Linking Coal Mining, Fish Farming, Water Conservation and Recreation. Journal of Applied Aquaculture. Vol.15 pp.159172.

Semmens, K. J., and Miller, D., 2003. Utilizing Mine Water for Aquaculture. Proceedings of the International Water Conference, Pittsburgh Pennsylvania, October 19-23. IWC-03-24.

San, N, Miller, D., D’Souza, G., Smith, D.K., and Semmens, K. 2001. West Virginia Trout Enterprise Budgets.Version 2.0. WVU Extension Service. Pub. \# AQ01-1.

Miller, D., Mora, O. and Criollo, F (1994) A Practical Diagnostic Method for Determining Intestinal Gregarine Infection in Penaeus vannamei on a commercial shrimp farm_ World Aquaculture: Vol. 25 (1) 65-66.

Miller, D., Mora, O. and Criollo, F. (1991) Analysis de Nematopsis en P. vannamei; Aquacultura del Ecuador: No.15, 1991 pp.18-20.

Miller, D., Mora, O. and Criollo, F. (1991) Analisis de Nematopsis; Aquacultura del Ecuador: No.16, 29-30.

Miller, D.J., Criollo, F. and Mora, O.; (1994) Quantifying Gregarine Infestation of Penaeus vannamei on a Commercial Shrimp Farm and Some Attempts at Treatment NAGA The ICLARM Quarterly: July 1994,30-31

\section{Grants / Awards:}

Best Student Presentation: 2007 VA/WV Water Research Symposium Roanoke, VA. Nov. 28

Best Poster: Aqua 2006 (World Aquaculture Society) Florence, Italy May, 2006 Grants: U.S. Geological Survey: \$74,000 - Mine site aquaculture development. U.S. Dept. of Commerce: $\$ 10,000$ - Water treatment demonstration project at mine discharge site.

McDowell Co. Economic Development Authority: \$3,000 - Mine site demonstration project.

Eastern Associated - Tygart River Mine: \$18,000 - Recreational Use of the Guyses Run site.

Eastern Associated - Robin Hood \#9 -\$31,000 Flow study and fish demonstration project.

WV Division of Tourism: \$2,500 - Fee Fishing Brochure Development and Distribution. (2003, 2004) 


\section{Member:}

Technical Industry Advisory Committee - Northeastern Regional Aquaculture Center (2003-2005)

Aquaculture Certification Council - Inspector

World Aquaculture Society

Rotary International

Habitat for Humanity 